\title{
Spatio-temporal variation of the structural organization of demersal communities in the Southwestern Gulf of Mexico
}

\author{
Daniel Torruco ${ }^{1}$, Ernesto A. Chávez ${ }^{2}$ \& Alicia González ${ }^{1}$ \\ 1 CINVESTAV- IPN, Km 6 carretera Antigua a Progreso A.P. 73, C.P. 97310 Cordemex, Mérida Yucatán, México; Tel: \\ (99) 81-2903 ext. 298. Fax: (99) 81-2917, dantor@mda.cinvestav.mx \\ 2 CICIMAR, Playa el Conchalito s/n A.P. 592, 23000 La Paz, B.C.S., México.
}

Received 04-X-2002. Corrected 13-VII-2006. Accepted 28-II-2007.

\begin{abstract}
Structural patterns of a sublittoral community were analyzed through a two-year series of samples in the Southwestern Gulf of Mexico. The groups involved in the study comprise fishes, molluscs, echinoderms and crustaceans. The time-space progressions of Second 0rder diversity values range between $\mathrm{N}_{2}=5.3$ and $\mathrm{N}_{2}=9.8$ at depths of 40 and $20 \mathrm{~m}$ respectively, through the first year of samples. In the second year the highest value $\left(\mathrm{N}_{2}=22.2\right)$ was found at $30 \mathrm{~m}$. The community ordination data through cluster and principal components analysis show five assemblages: benthic, benthic-demersal, demersal, mid water column, and temporary. There is a striking difference in trophic web structure between the dry season and rainy season. Fish community resource partitioning shows that the components are organized in three guilds: ichthyophagous, carcinophagous and omnivorous. However, a partial overlap of niches was commonly observed, and juvenile stages showed a narrower trophic spectrum than adults. Rev. Biol. Trop. 55 (2): 509-536. Epub 2007 June, 29.
\end{abstract}

Key words: marine invertebrates, fish, community composition, diversity, trophic spectrum, Gulf of Mexico, Veracruz.

The Veracruz shelf environment is a complex interaction of adjacent land masses, coastal waters near shore influenced by estuarine systems and their inherent high productivity, coastal lagoon input, and dynamics of open Gulf of Mexico waters. Relatively high surface water temperatures of the Gulf bring about a great warming and an increase in moisture content in overlaying air masses. Water mass distribution in open Gulf waters results from inflow through the Yucatan Channel, outflow through the Straits of Florida, surface conditions created by local air-sea exchange processes, and internal mixing of three welldefined water masses from the bottom up: Gulf basin water, a layer of the Antarctic intermediate water and a Mid-Atlantic element (Merino 1986). The hydrography is a mixture of these elements and is important as the basic setting for the resultant biological communities, which are a reflection of it. The variability in spatial and seasonal production of the demersal fauna along the shelf is important in the balance of organic matter in the water column (Merino 1987).

Identification and description of community patterns are some of the main contributions of numerical ecology. The quantitative multispecies approach enables the identification and discrimination of slight differences in community structure (Orlóci 1978a, Chang and Gauch 1986, Bachelet et al. 1996). Furthermore, it offers an objective summary about the community which is easy to communicate (Gnanadesikan 1977, Pielou 1984). Most of the previous studies of this type within the Gulf of Mexico describe the fauna associated with important fishery resources (Gunter 1945, Hildebrand 1955), or in relation to environmental gradients (Boesh et al. 1977), 
faunal relationships with natural disturbances (Thiestle 1981, Flint 1981), resource allocation (Thorman 1983); interspecific relationships (Watzin 1983, Gilinsky 1984), or the representation of the main properties of structure and dynamics of the community through simulation models (Hughes 1984, Pennington and Godø 1995). The continental shelf ecosistem of Veracruz coast supports valuable comercial fisheries, particularly of penaeid shrimp. The present paper presents a space-time analysis of a sublittoral community abundance (macroinvertebrates and fishes), in a coastal area of the SW Gulf of Mexico.

\section{MATERIALS AND METHODS}

Study area: the study area is a $10 \mathrm{~km}$ offshore strip, $80 \mathrm{~km}$ north of the City of Veracruz in a region where hills of igneous rocks of the Sierra Madre Oriental are in contact with the shoreline, which in this place is a mixture of sandy beaches and rocky shores (Fig. 1). The area where samples were collected shows a gradient of substrata, varying from sandy bottoms in the shallower depths, to muddy into about 18-20 $\mathrm{m}$ depending upon wave action.
From $20 \mathrm{~m}$ depth downward, is consistently muddy bottom.

Faunal and environmental sampling: sampling was carried out monthly during the first years and every three months during the last. The samples were obtained by using a test shrimp try-net ( $3 \mathrm{~m}$ long, 2.5 mouths and 3/4 inch mesh; the trawls were for $30 \mathrm{~min}$ at 1.5 knots of vessel speed) at $10 \mathrm{~m}$ depth intervals from at $10 \mathrm{~m}$ to $50 \mathrm{~m}$. Two or three replicate samples were taken at each depth. Some months and depths were not sampled because of bad weather. The number of individuals of each species were determined for each sample and recorded; the community diversity was analyzed using the second order diversity index (Hill 1973, Ezcurra 1980); this index allows calculation of community evenness. The sediment fractions were evaluated using the Bouyoicos technique, and the proportion of weight of organic material by combustion of the organic fraction and substrated from the total weight. On the other hand, dissolved oxygen measured in the lower water column nearshore: was less than $18 \mathrm{~m}$, often showing higher values (6 to 8 $\mathrm{ppm}$ ) than those recorded in deeper waters ( 3 to $6 \mathrm{ppm})$, this factor was evaluated by standard

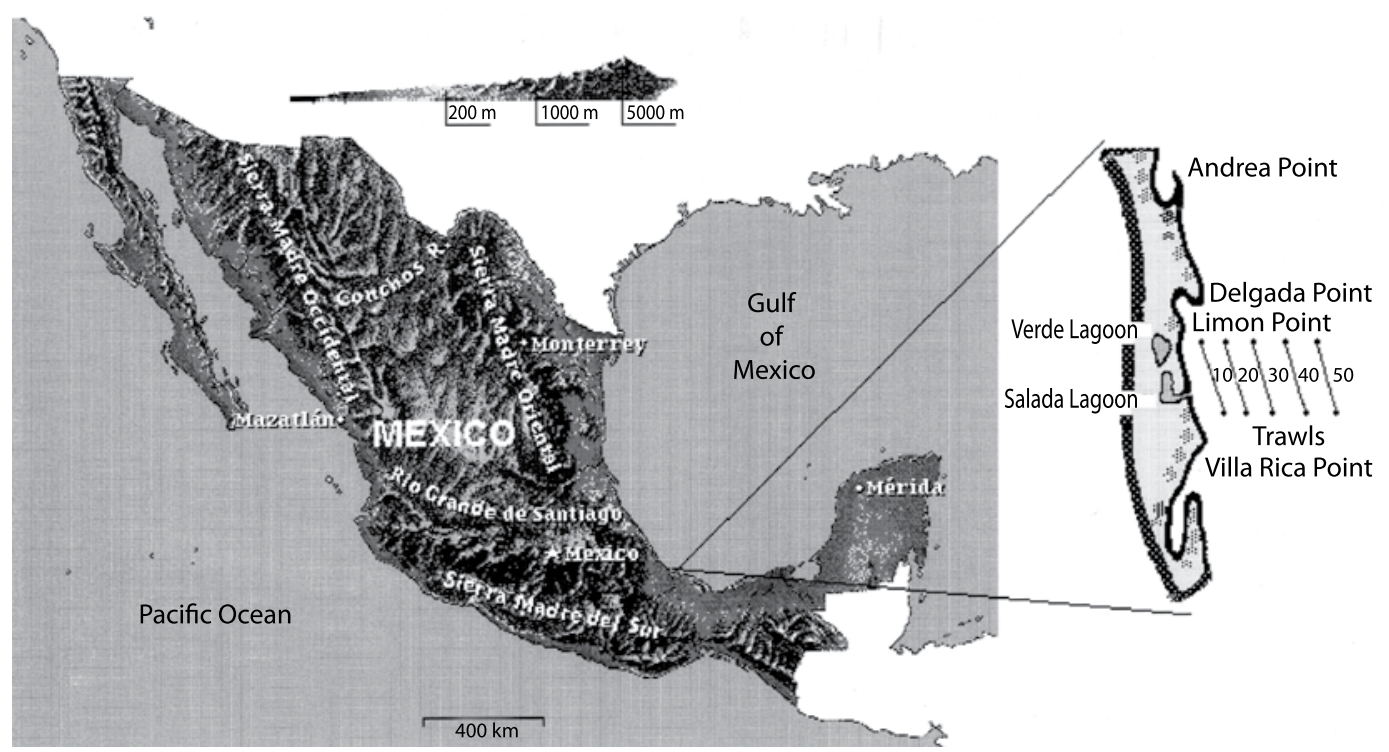

Fig. 1. Map showing locations of the sampling site. The isobats (10 to $50 \mathrm{~m}$ ) show the trawls in both years. 
methods (Strickland and Parson 1972). The temperature and salinity were registered with YSI85; for each parameter we took three readings during each trawl and utilizing the average for the characterization of each depth.

Faunal and environmental analysis: matrices of species abundance (catch /trawl) with respect to depth and season were root-root transformed; however, when proportions were used, the arc-sine of the square root was taken instead (Bireley 1984). The cluster analysis was carried out by means of the cordal distance index (0rlóci 1978b), and the resulting matrix was grouped using of the flexible method with $\mathrm{B}=-0.25$ (Sneath and Sokal 1974, Swartz et al. 1986). For the community ordination, principal components analysis was used. The environmental variations were evaluated by kriging technique with a linear variogram model, because the data points were evenly dispersed in the area (Axis et al. 2001). In order to know the relationship between the abundance and the recorded parameters, a non-parametric analysis, the Spearman's correlation was carried out. The diet data of the most important fish species in one year were analyzed using the similarity coefficient (Horn 1966). The sampled fish were injected with formol at 40 $\%$ in the stomach in order to stop any digestive process, subsequently, the stomach contents were dissected and analyzed. The composition of each trophic group was evaluated as the percent of the total area of the stomach content; the comparative weight value and the frequency of each food item were used to define the trophic spectra (Overstreet and Heard 1982). Values obtained are an average for each species; Fig. 8 shows the size and number of analyzed specimens. The Horn's similarity index gives a relative value of trophic overlap (Rice 1988). The analysis was carried out both with and without considering detritus as a component of the food consumed.

\section{RESULTS}

Environmental variations: the annual variation of the three analyzed parameters were presented in the first period, high values between May and September, the lowest values were registered in November-January in all the depths, increasing their values towards March-April to the depth of $10 \mathrm{~ms}$. The salinity presented high values in May-June to 30-40 m, the minim was in October in the rainy season. Oxygen showed to high values in February in all the depths whereas in the rest of the year it had intermediate values with exception of September to $30 \mathrm{~ms}$ where the lowest value was registered; in spite of this, the minimum values were in supersaturation (Fig. 2). The second cycle showed small variations, but such changes can be the effect of the separation of the sampling. Comparing months in both cycles (Fig. 2), the temperature shows a seasonal pattern, with nodules of high concentration in May for first and September for the second. The salinity presents nodules of high concentration in May extending until September in both cycles. Although oxygen has variations with the depth, it presents high values in February and minimums in November in both cycles.

Diversity and relative abundance: a total of 4739 specimens of molluscs, echinoderms, crustaceans and fishes were caught (Table 1). The most abundant families were Penaeidae, Portunidae, Triglidae, Carangidae, Sciaenidae and Bothidae. The diversity values by month and depth for both years and mean by depth and season are shown (Fig. 3); the range in diversity during the first year was $\mathrm{N}_{2}=9.8-5.3$ at 20 and $40 \mathrm{~m}$ respectively, and the equitability range from 12.6 to 4.8 , at 30 and $20 \mathrm{~m}$. Seasonally, the values ranged from $\mathrm{N}_{2}=8.8-2.9$ in February and March respectively, whilst the equitability showed two maxima, in June and March (8.8 and 7.2) and two minima, in August 

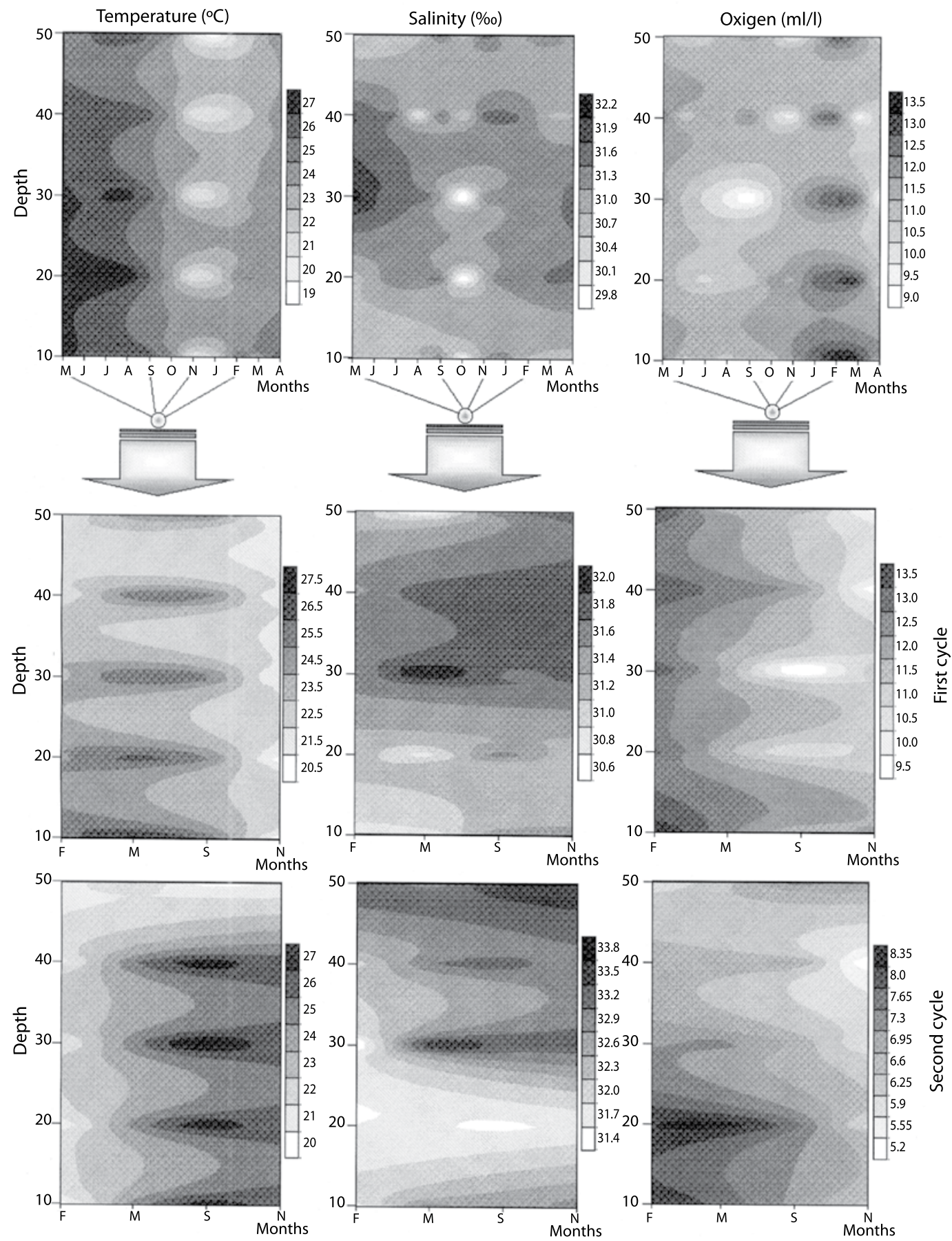

Fig. 2. Spatial distribution of the environmental factors in the study site in both periods. The monthly variability is presented for the first cycle. 


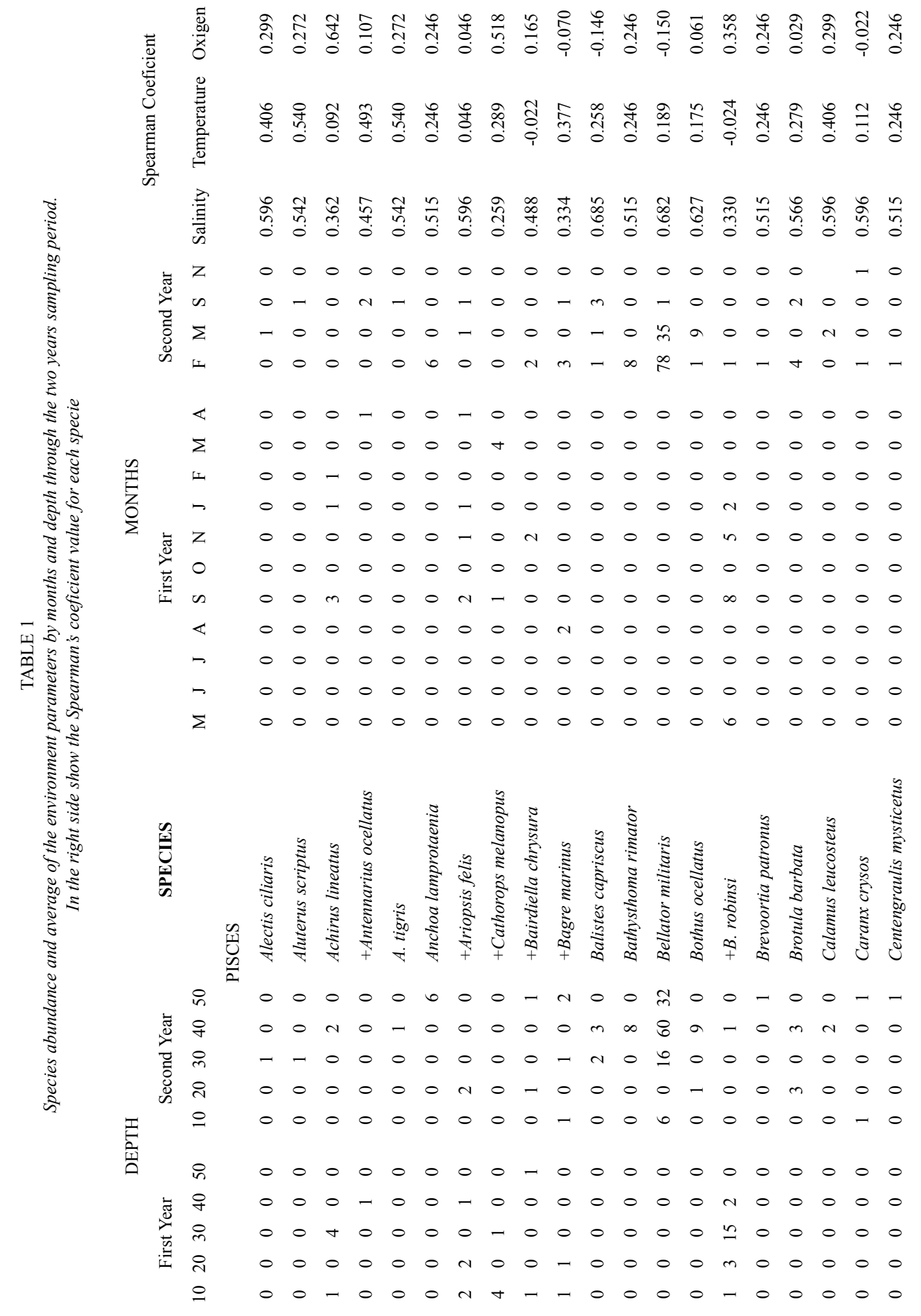




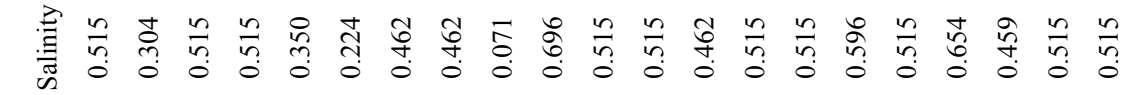

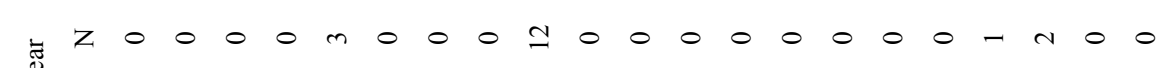

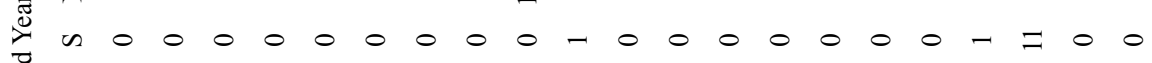

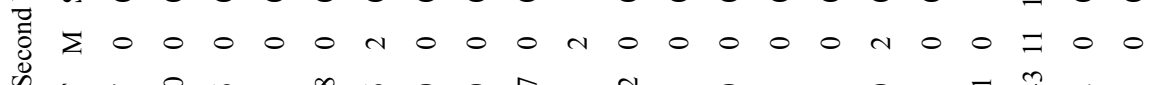

$\varangle 000000000-0000000000000000$

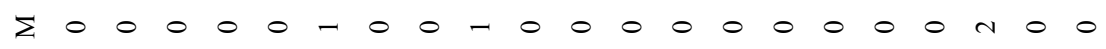

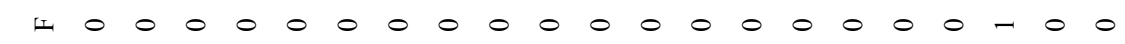

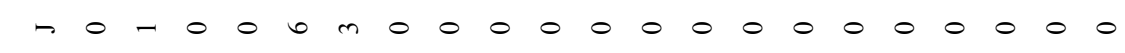

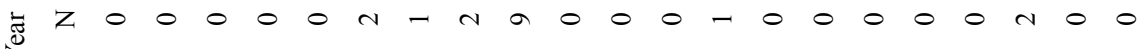

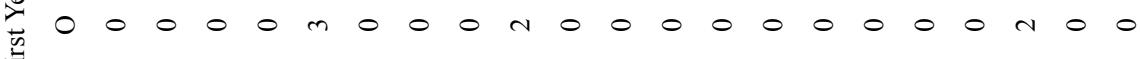
n 0000 - 00000000000000000

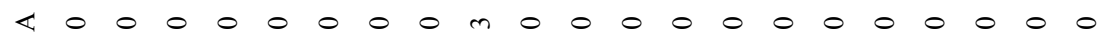

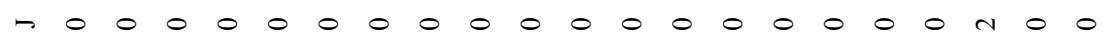
$-0-000 \mathrm{~m} 000000000000000$

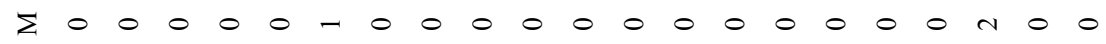

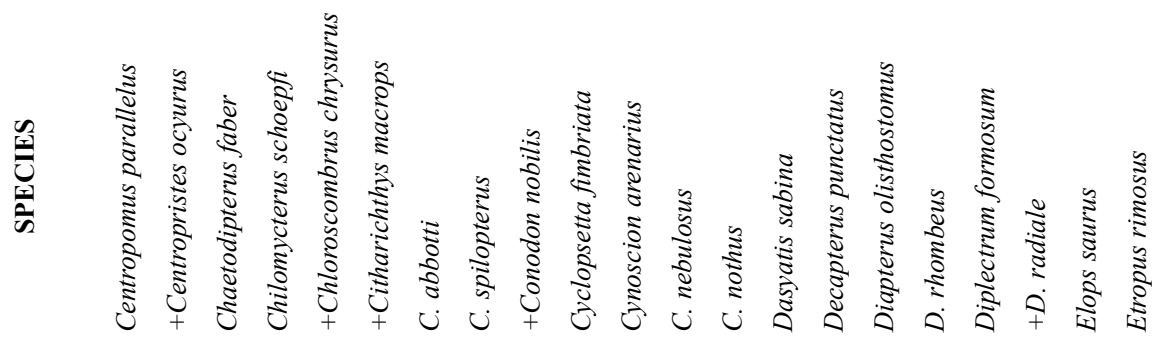
in $N$ N

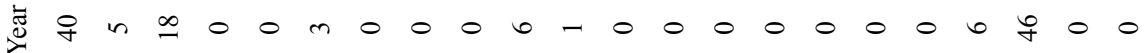

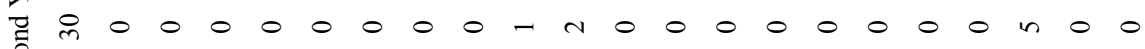

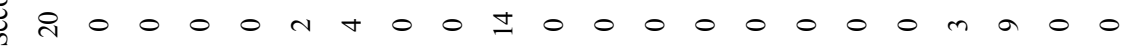
壳

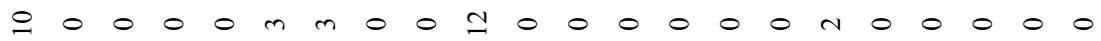

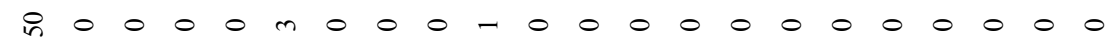

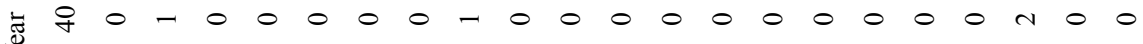

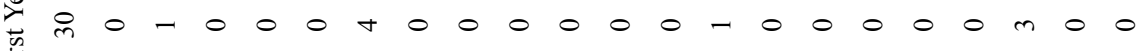

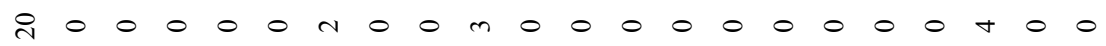

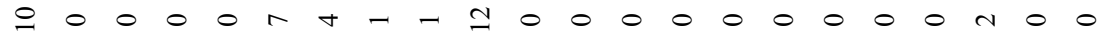




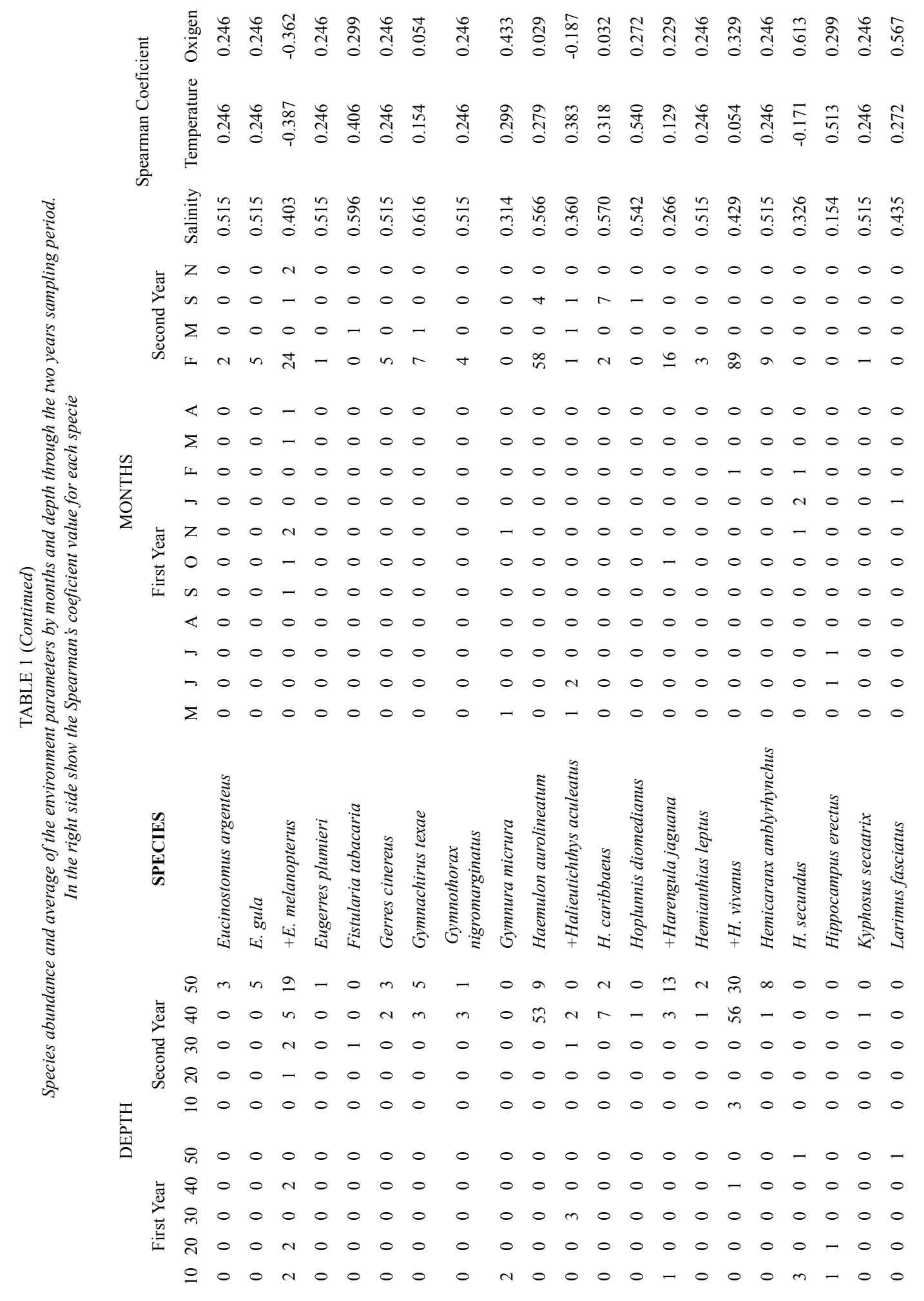




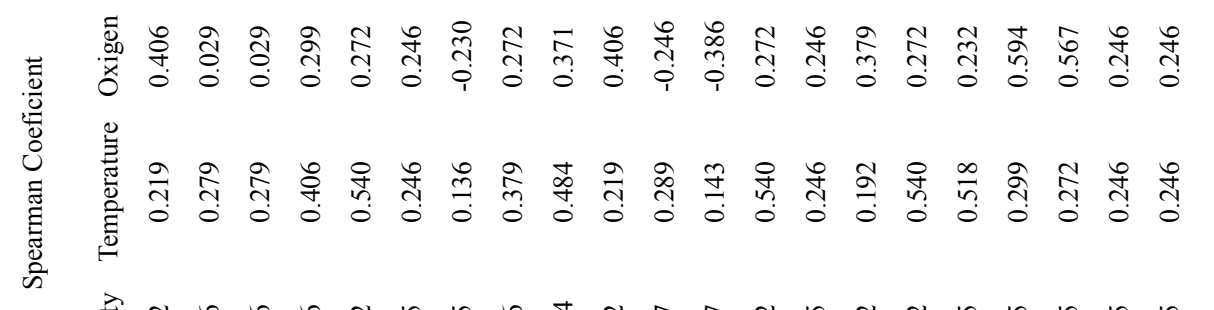

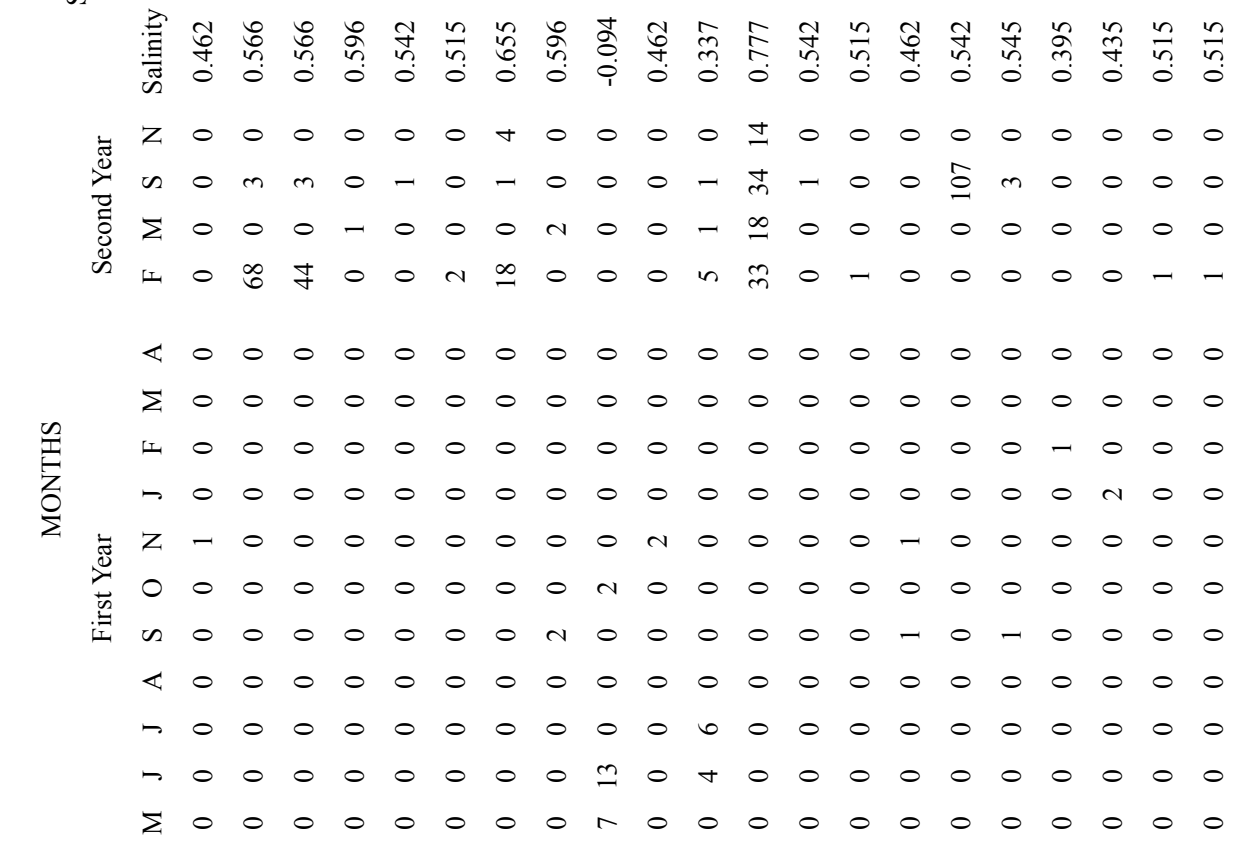

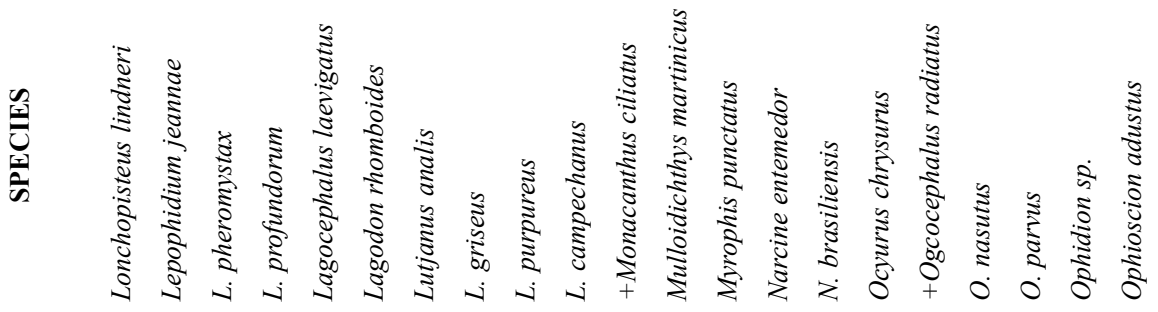

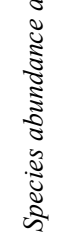

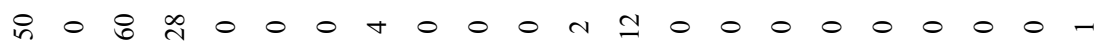

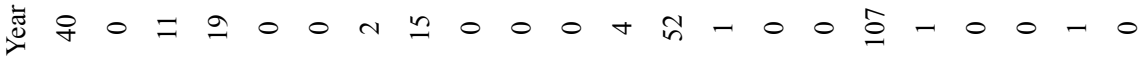

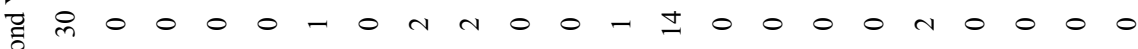

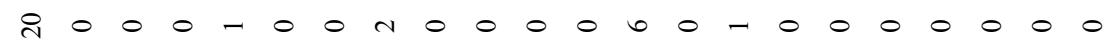

$$
\begin{aligned}
& I 000000000000 \text {. } \\
& \text { 武 }
\end{aligned}
$$




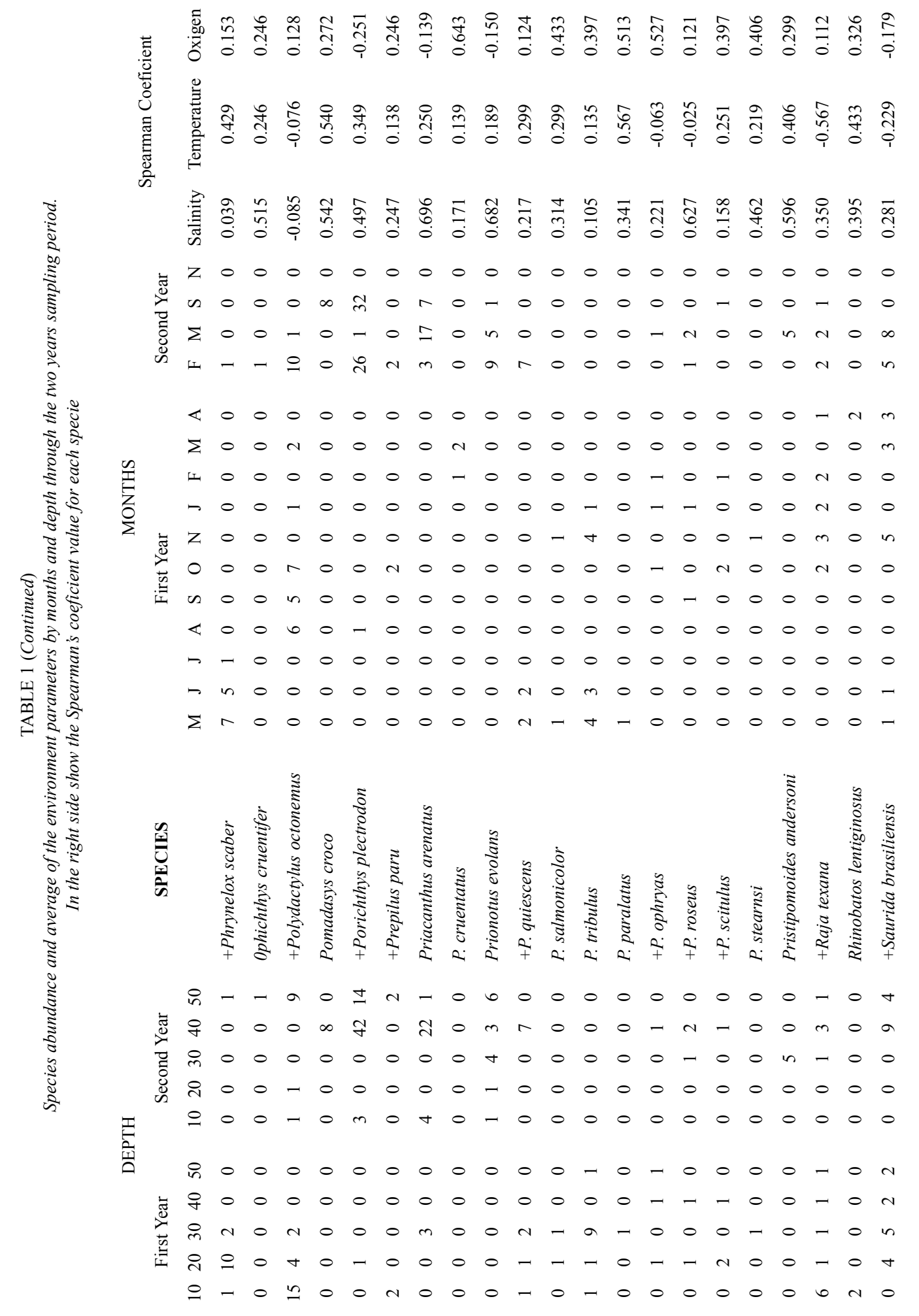




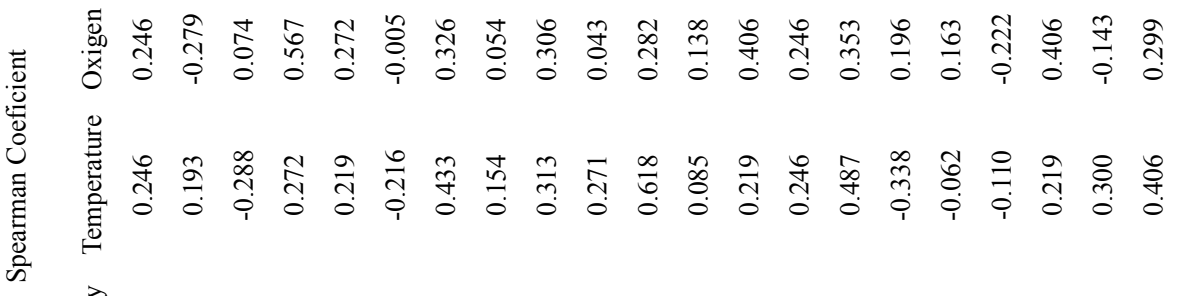

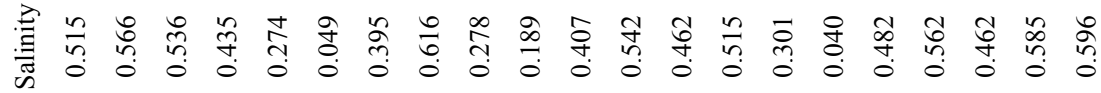
\# Z

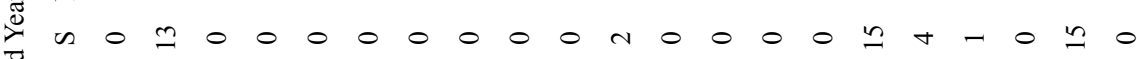

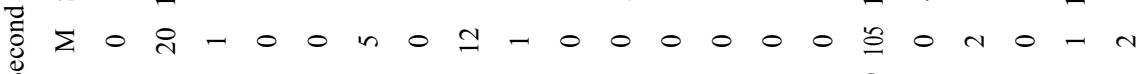
I

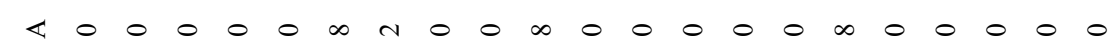

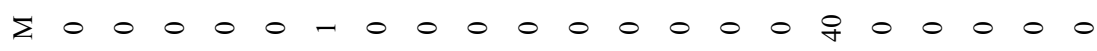

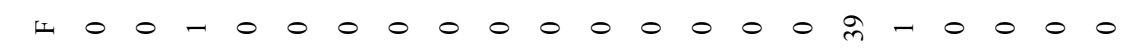

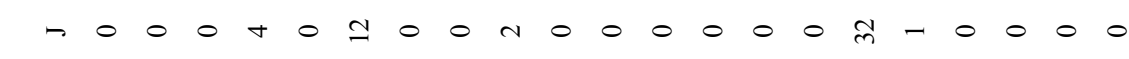

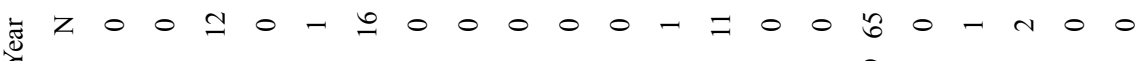

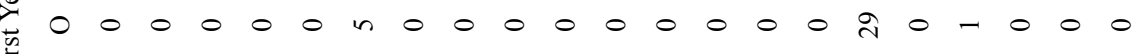
u 0000000

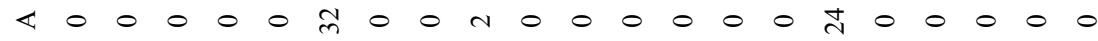

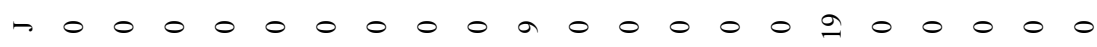

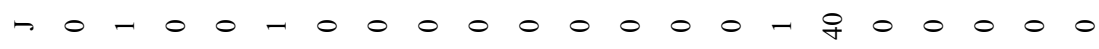

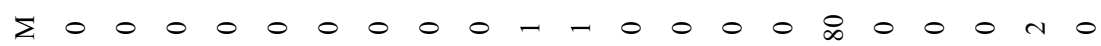

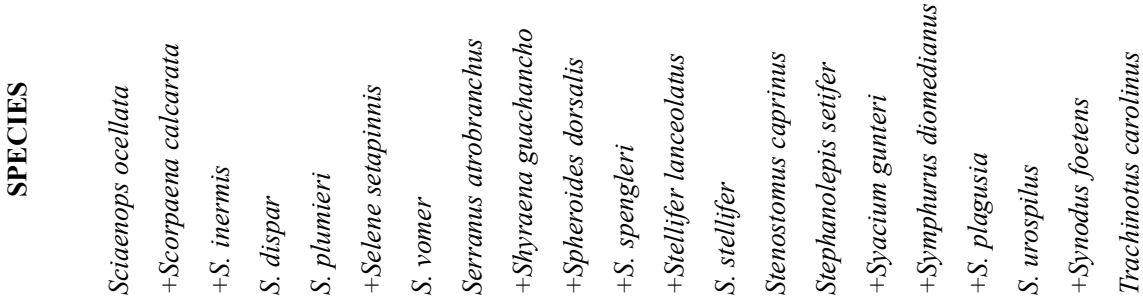

에

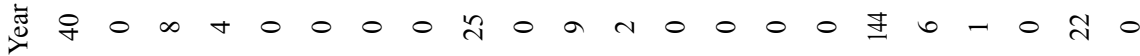
J 㞫 声 이 $0000-0 m 00000000000 \mathrm{~N} 0$

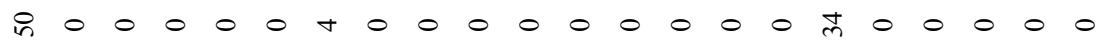

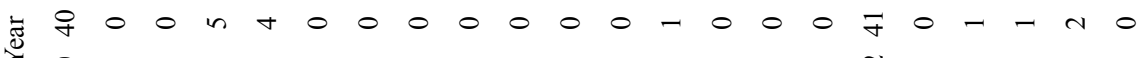

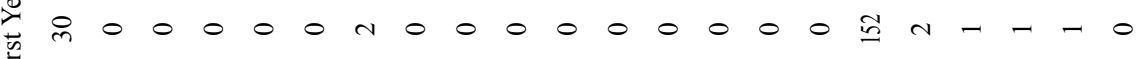

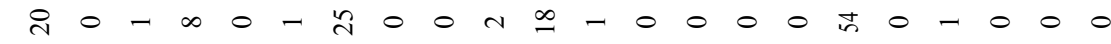

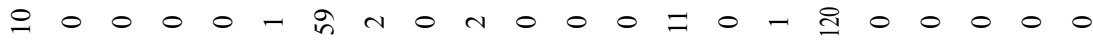




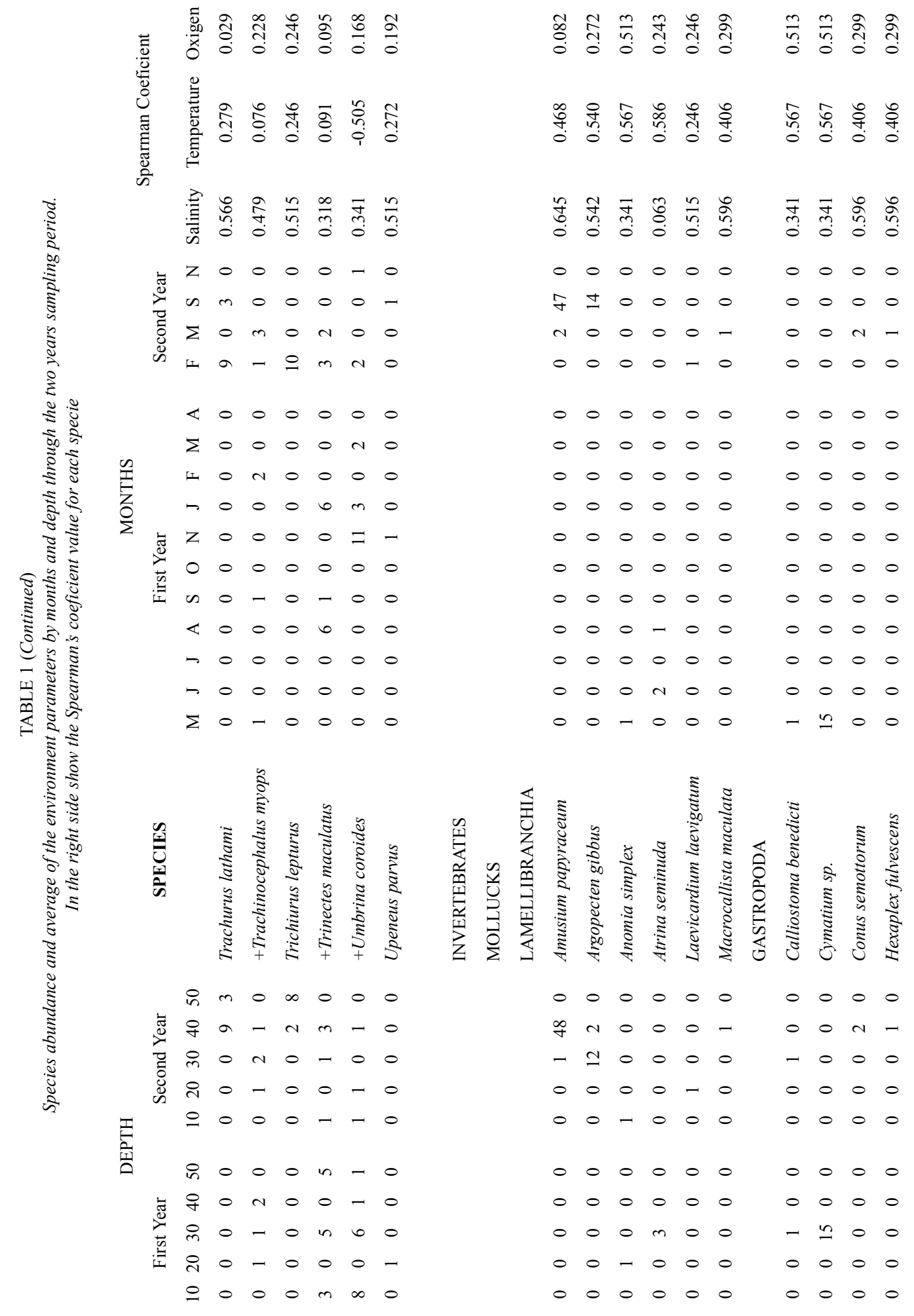




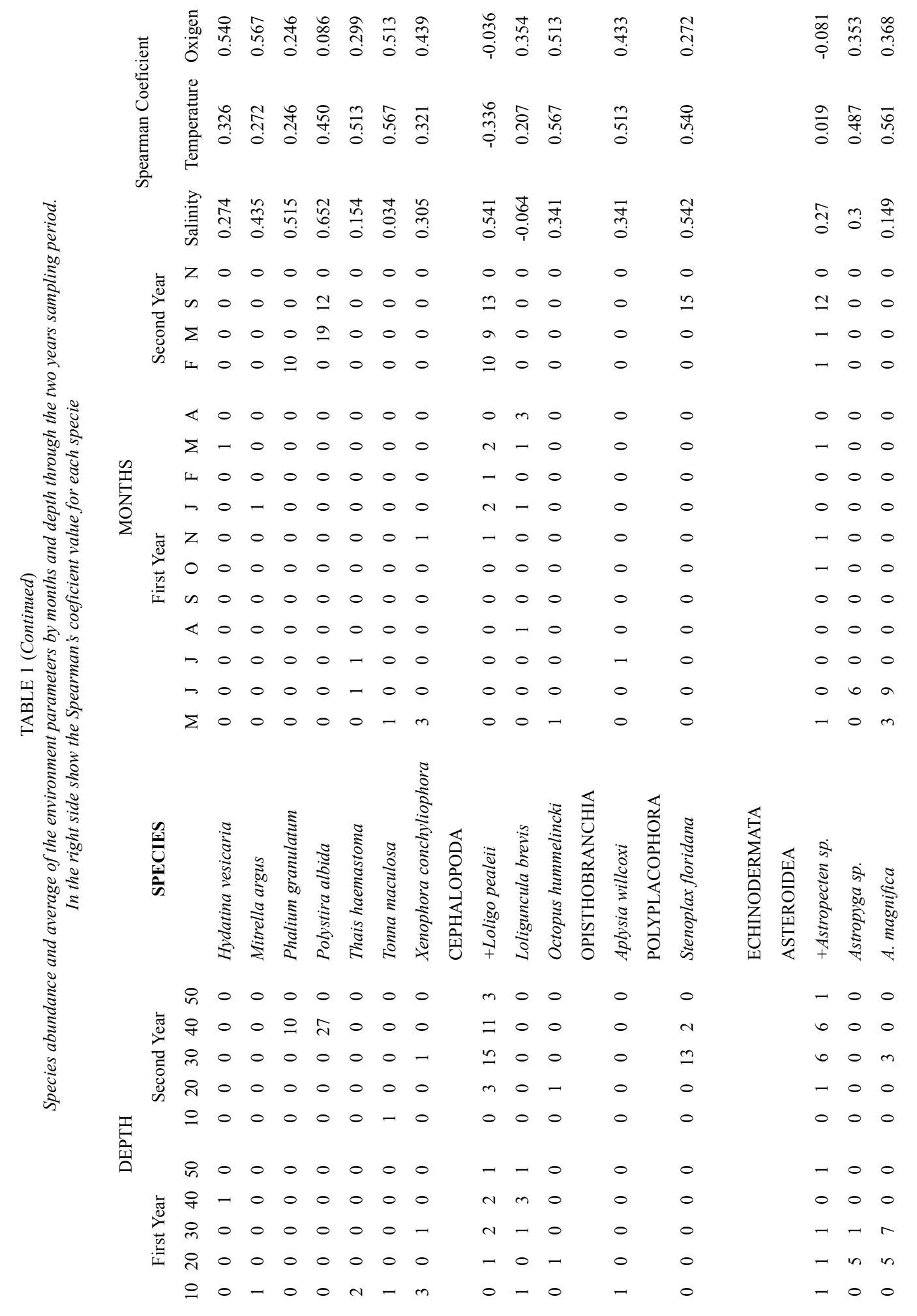




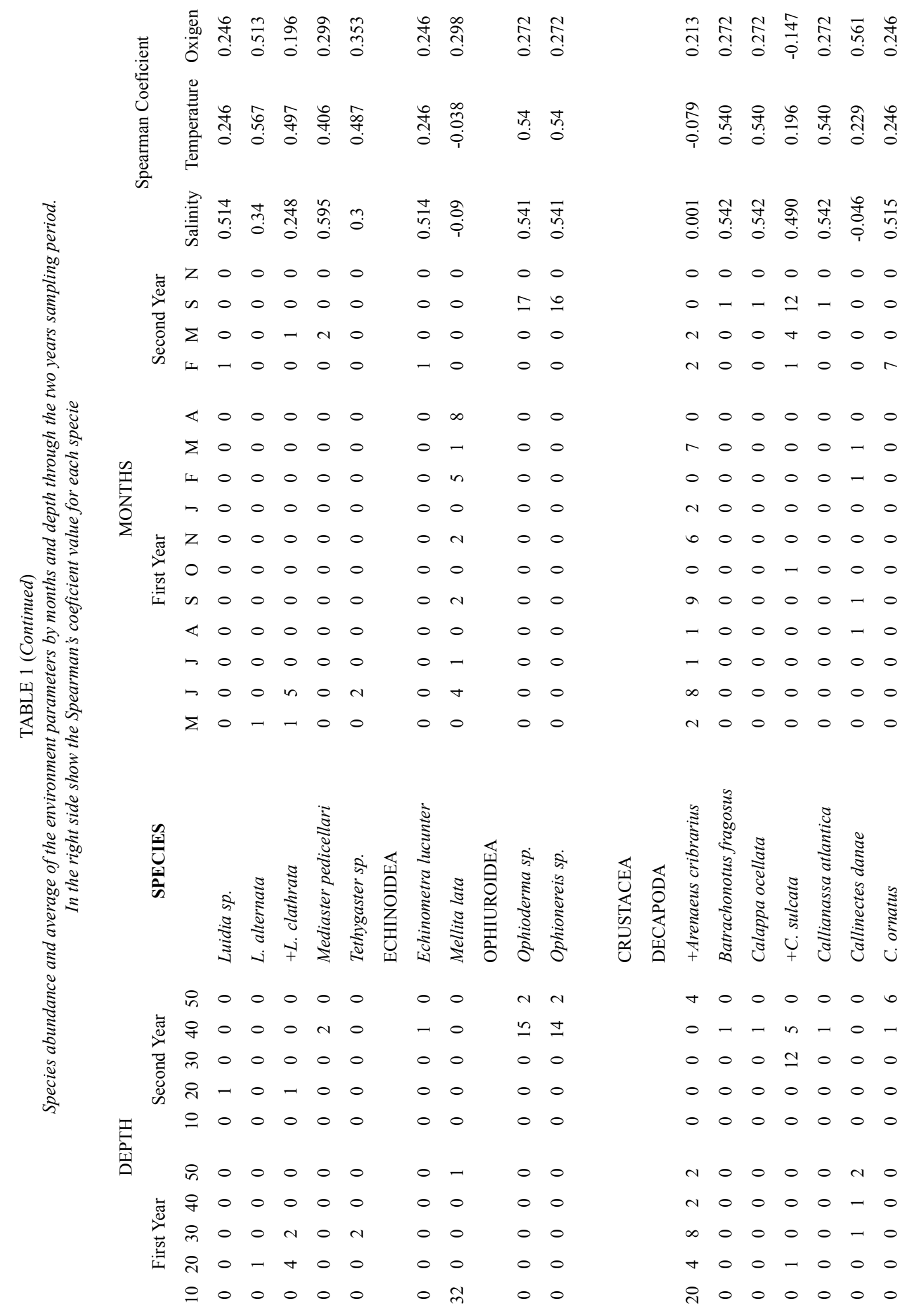




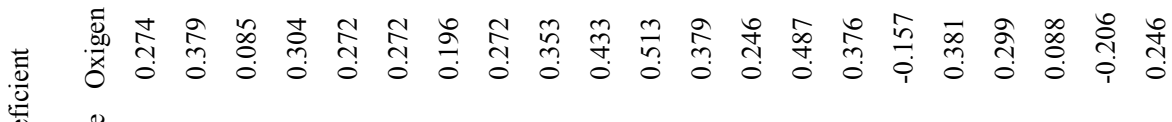

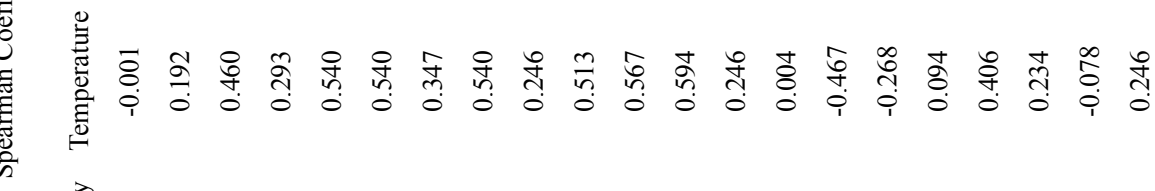

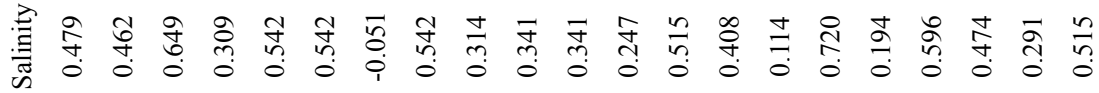

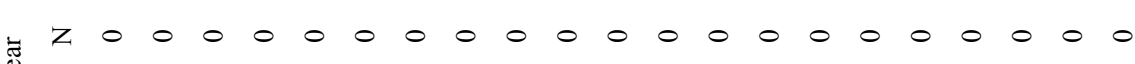
证 0 O 苛 $\Sigma 00--000000000-n$ N

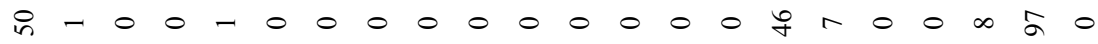

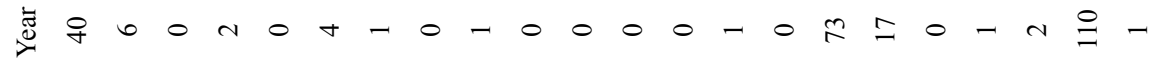

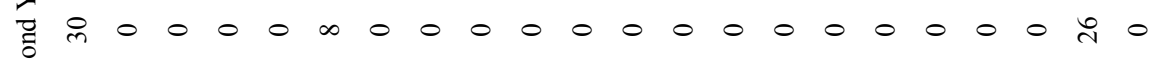

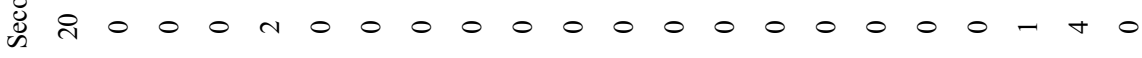
$\exists=0000000000-0000000000$ 武

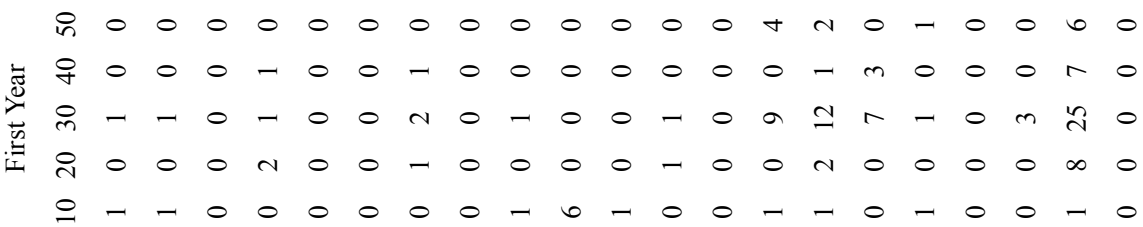




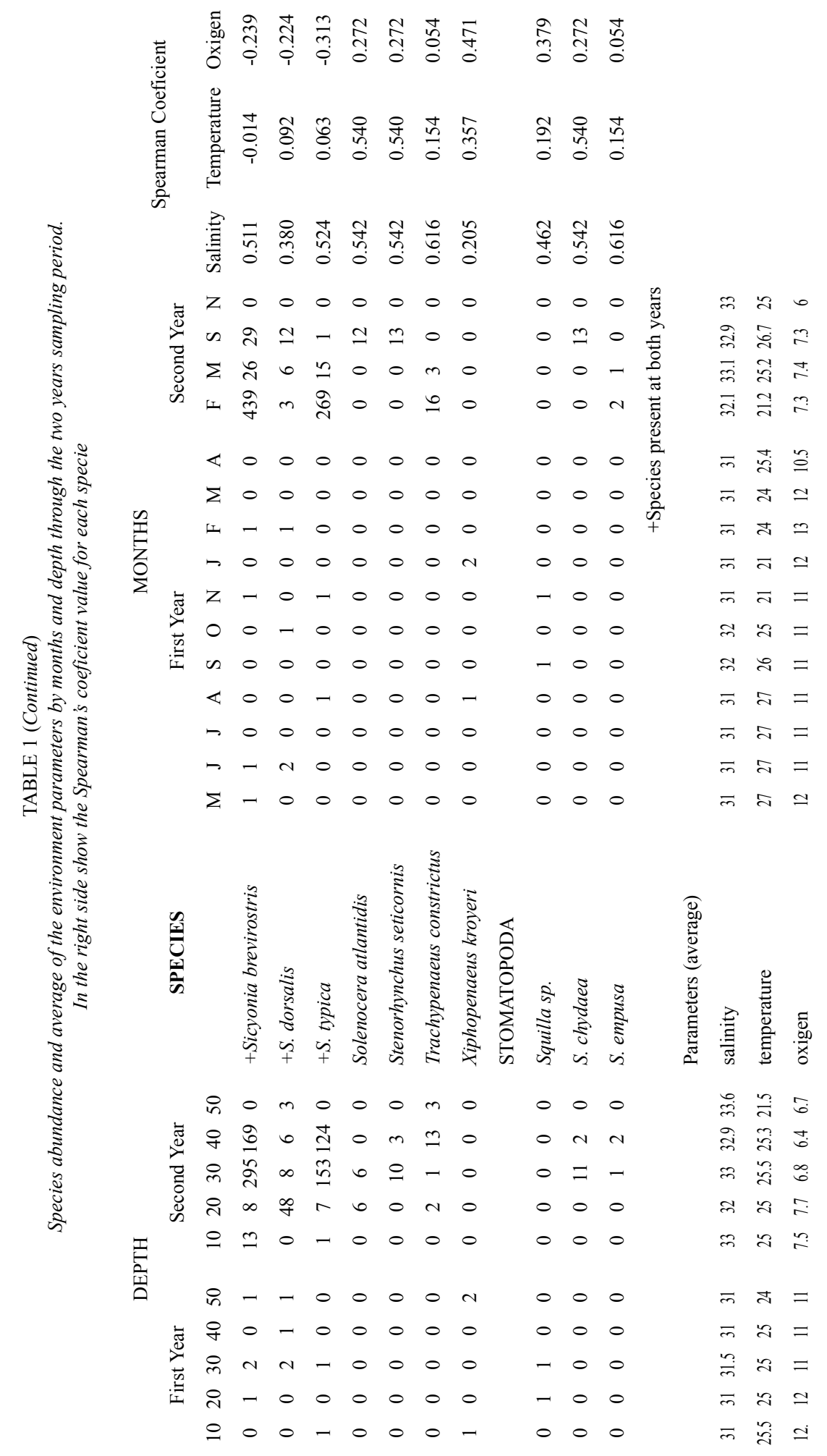


and May (2.6 and 2.4). During the second year, the highest value (2.2) was found at 30 $\mathrm{m}$, decreasing both toward the deeper and shallower grounds; equitability behaves in a similar way. The maximum diversity was observed in September and the minimum in November (16.2 and 5.4); the maximum equitability was observed in February whilst the lowest was in November (7.1 and 2.2; Fig. 3).

Community patterns: the cluster analysis were carried out on the first cycle data groups at similar depths in June-July, November-January and March-April (Fig. 4). During the second cycle, mean depths were consistently pooled at very low similarity values. The seasonal variation of the community shows that the fishes were organized into three well-defined groups, one through November, January and February, linked to low temperatures and north winds; the second group was consistently evident through March, April, June and July; the first two months belong to the dry season, whilst the last two correspond to the rainy one. The third group was organized during a period in transition between the rainy and the cold season (Fig. 5). The benthic portion of the community as grouped showed a similar pattern to that of fishes. Two seasons were clearly evident, one from July through November and the second one from January to June. During the second cycle there was no clear seasonal grouping to confirm same seasonal organizational pattern.

The classification of fish species falls into five complex groups. The first is formed by dominant elements in shallow waters, such as Cynoscion nothus (Holbrook), Prionotus paralatus (Ginsburg) and Symphurus diomedianus (Goode and Bean) among others. The second is a small group represented by Larimus fasciatus (Holbrook), Ogcocephalus parvus (Longley and Hildebrand) and Trinectes maculatus (Bloch and Schneider), all of them considered being benthic dwellers. The third group is also small and includes demersal fishes such as Antennarius ocellatus (Block and Schneider), Hemianthias vivanus (Jordan and Swain) and Lutjanus campechanus (Poey). The two remaining groups include a varied number of mixed species (Fig. 6). The invertebrates are organized into five groups: one contains up to 15 species including Portunus spinimanus (Latreille), Sicyonia brevirostris (Stimpson), Loligo pealeii (Lesueur) and Callinectes sapidus (Rathbun). While the most interdependence components of the second group are Callinectes similis (Williams) and Squilla sp. (Letreille). The third group includes only three species; the four groups have components with more interdependence Astropyga sp. (Gray) Thethygaster sp. (Caso) and Astropyga magnifica (Agazziz) Luidia clathrata (Say). The last group is composed of benthic components with high interdependence (Fig. 7).

The community structure during the first year of sampling appears to be consistently grouped around the depths of 20 and $30 \mathrm{~m}$ during the months of June, September, November and May. By contrast, in October, coincident with the beginning of the cold weather and northern winds, the organization of the community seems to partially break down and no real structure was discernible at any one of the depths sampled. The community reorganized itself during January, February and March in mid depths. It is noticeable that the components of the $10 \mathrm{~m}$ communities are not related with any other, probably because of the high energy and low physical stability of its biotope (Fig. 8 ). The second sampling period assembles all depths with the exception of $50 \mathrm{~m}$; May and September show more environmental homogeneity, while November seems to be more unstable physically due to the apparent lack of association. The annual patterns show two groups, shallow and medium depths reflecting the environmental driving forces.

Table 1 shows the value of Spearman's coefficient for the abundance of each species and the environmental factors; Table 2 shows the percentage of the species of each group that presented a negative relationship. In the fish, Polydactylus octonemus has correlationed negatively with the salinity and temperature; while Conodon nobilis, Diplectrum radiale, 

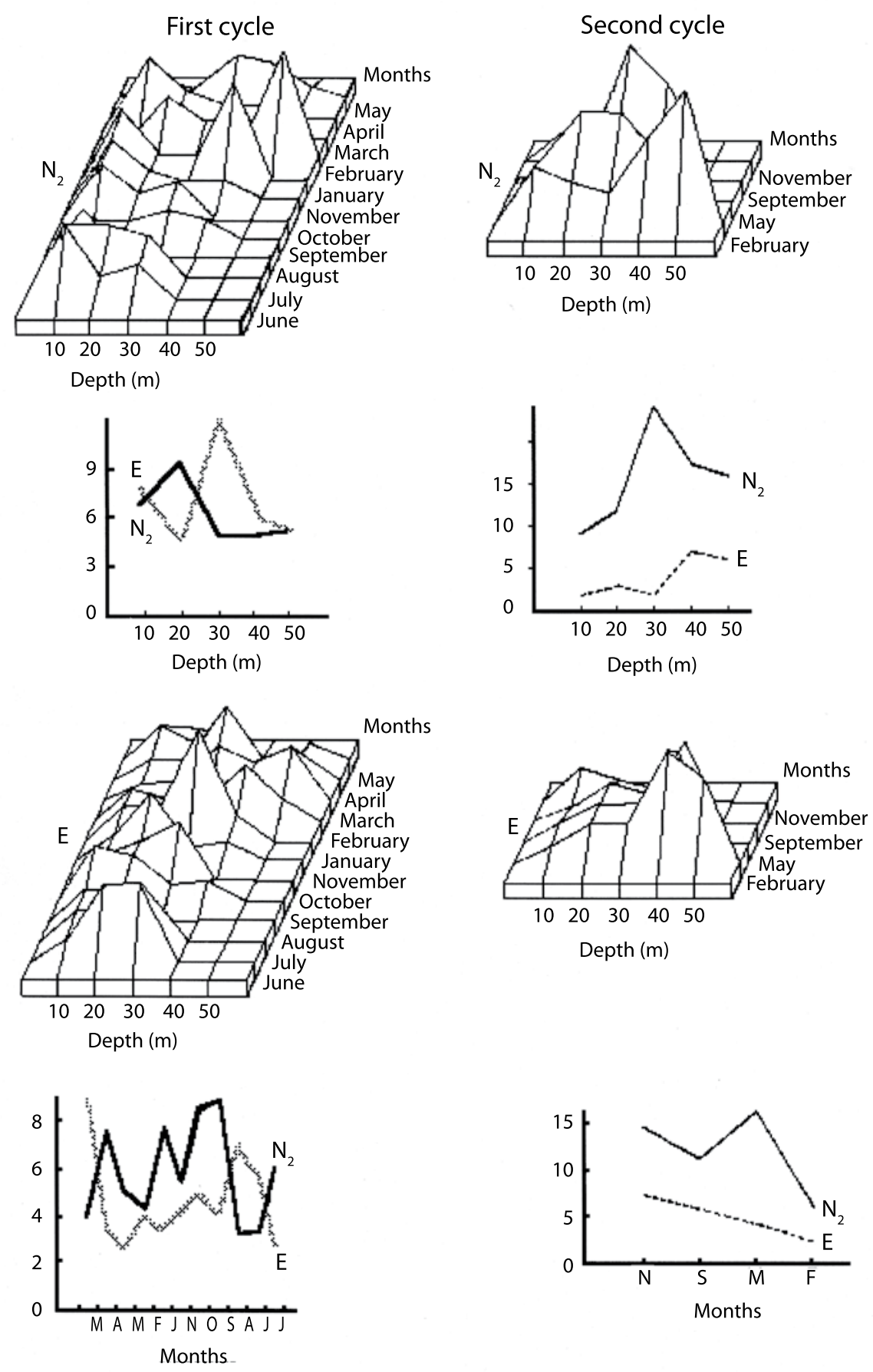

Fig. 3. Space-time values of second order diversity $\left(\mathrm{N}_{2}\right)$ and equitability (E) observed throughout two year of sampling cycles. On the left side, the $\mathrm{N}_{2}$ and $\mathrm{E}$ monthly tendencies with depth are observed. The graphs on the right show mean values of $\mathrm{N}_{2}$ and $\mathrm{E}$ done for the sampling depth and through the sampling times. 


\section{First cycle}
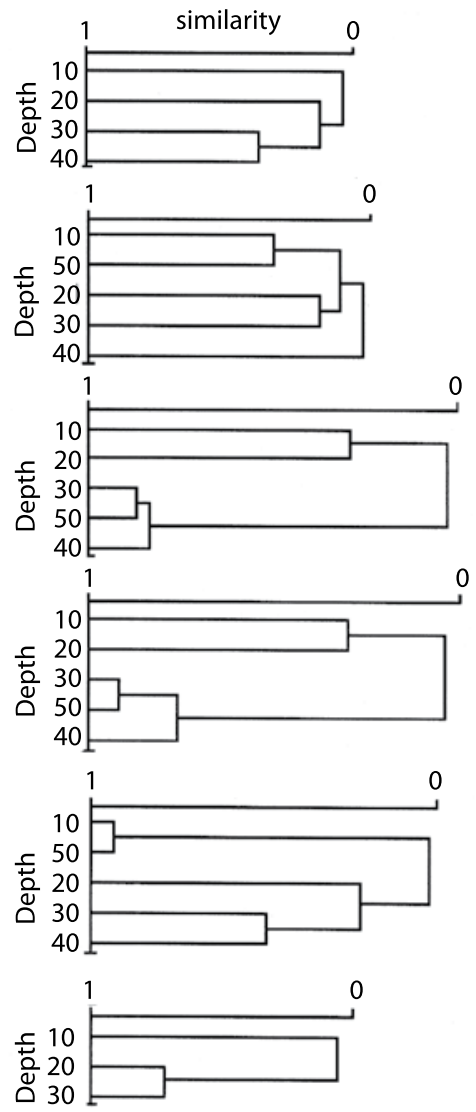

兵 $1 0 \longdiv { \square }$
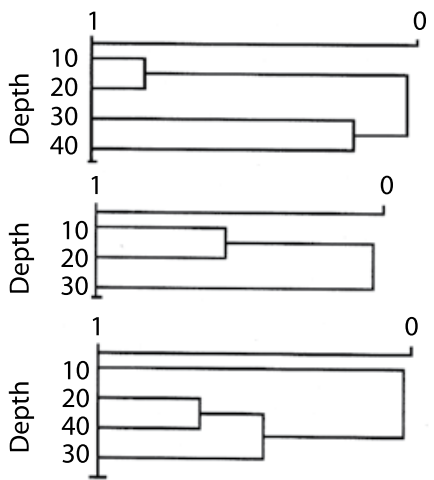

January

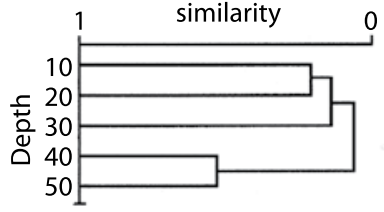

February

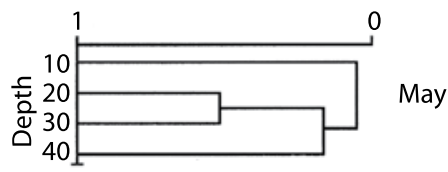

March

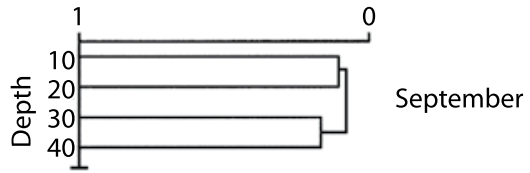

April

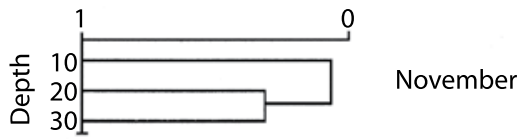

May

June

July

September

October

November

Fig. 4. Community cluster analysis. Data were sorted by months and depths with all fauna during each sampling month. 
First cycle

Fish
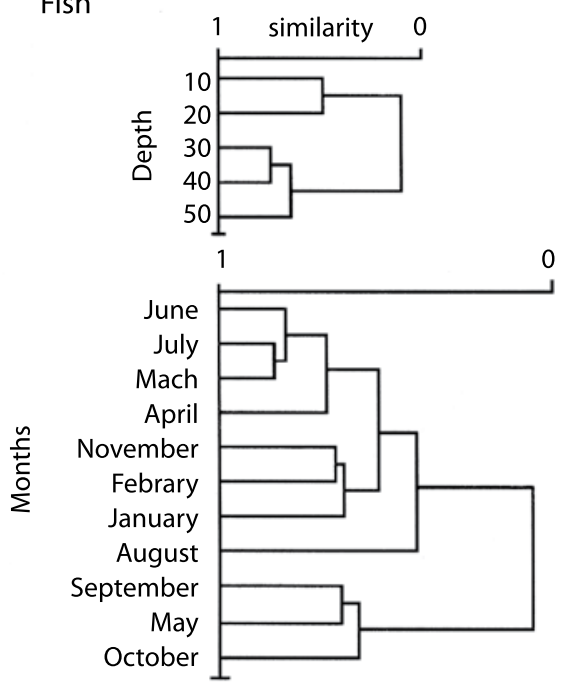

Invertebrates

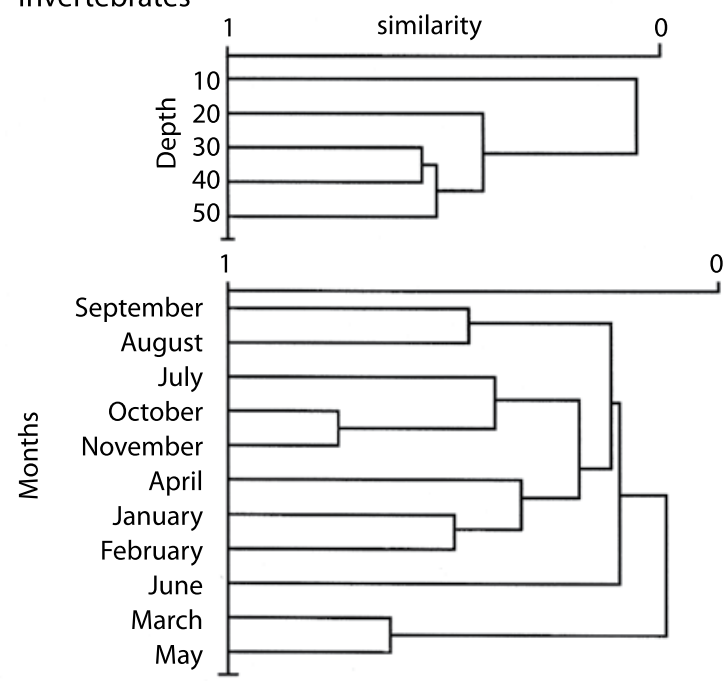

\section{Second cycle}

Fish
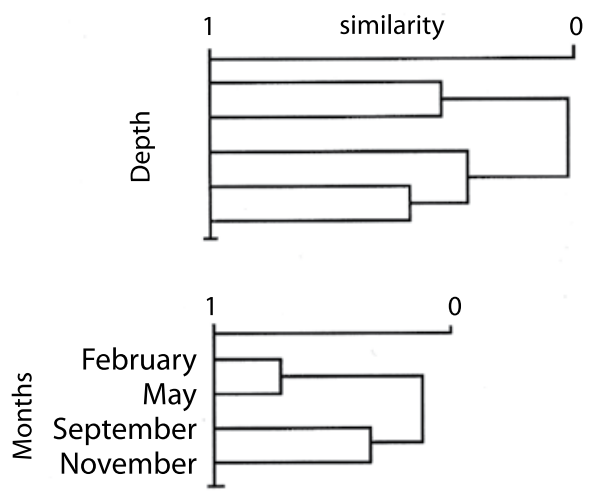

Invertebrates
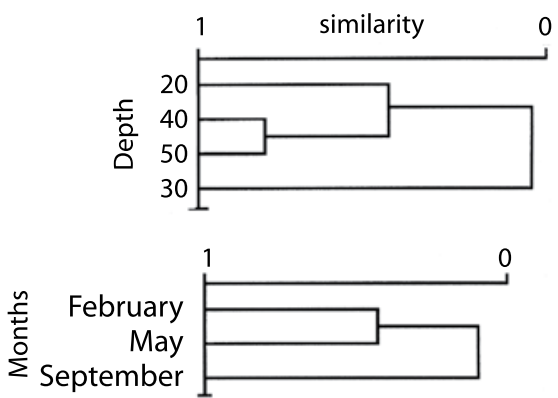

Fig. 5. Community cluster analysis. Data were sorted by depth, species composition, fish and invertebrates by separate, during seasonal sampling in both years. 


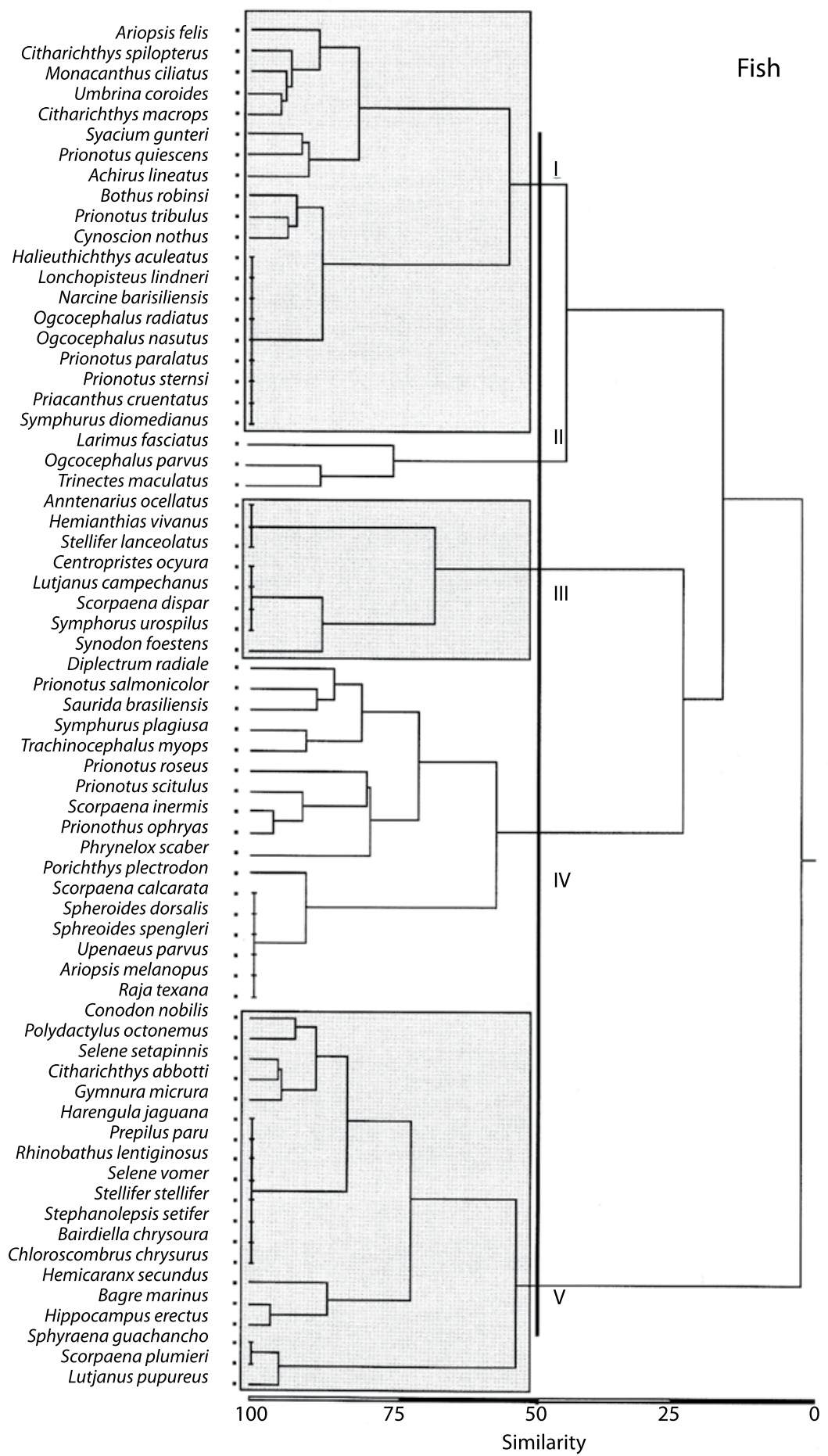

Fig. 6. Cluster analysis of fish species is organized into four main groups. Group I includes dominant species in shallow waters. Group II is formed by demersal species as well as group III. The remaining one group IV, is heterogeneous and in it there are elements which are trophically related to mid depths, linking surface waters with the bottom. 


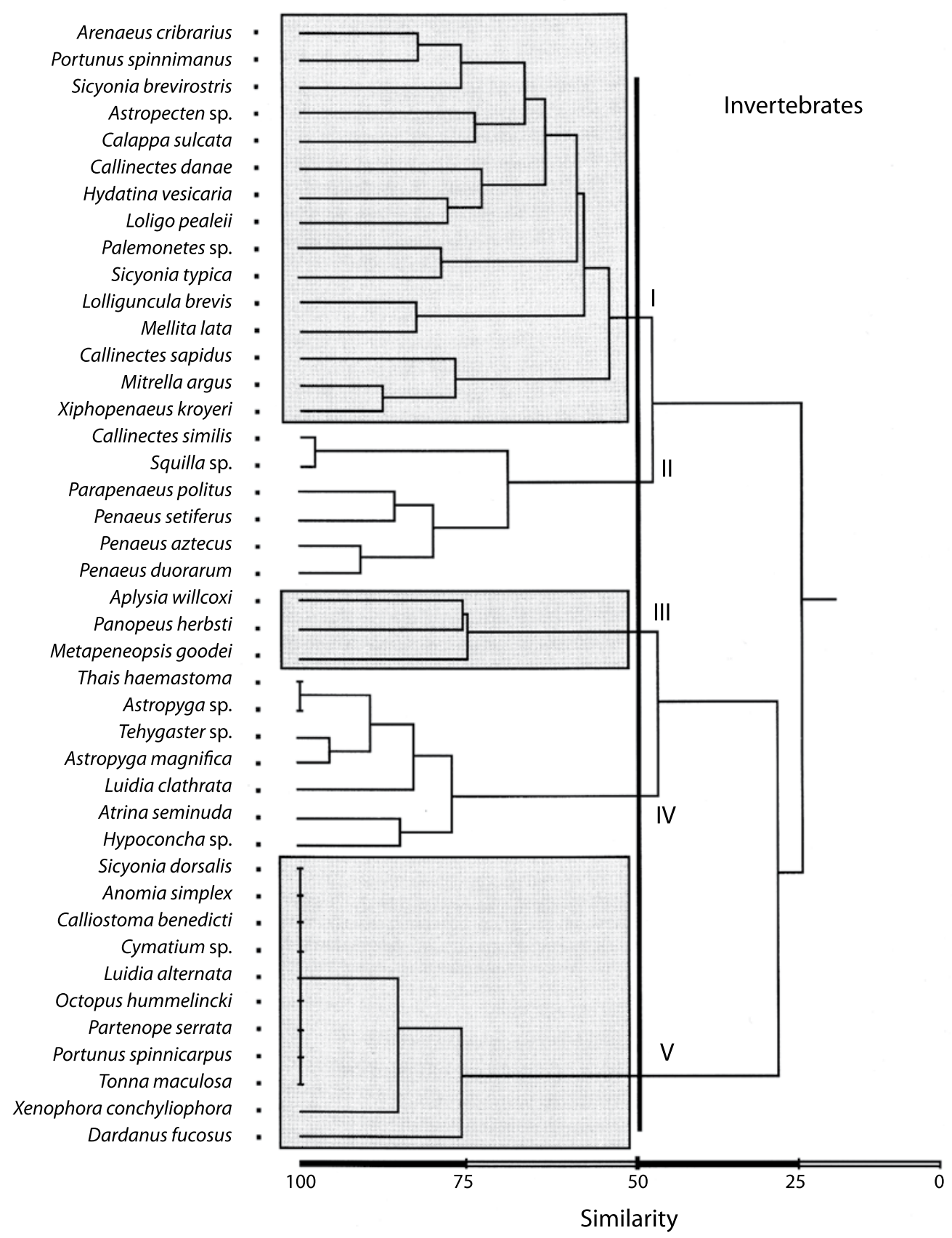

Fig. 7. Cluster analysis of invertebrate species. The community is organized into five groups. Most of the species are benthic dwellers and the groups are linked for habitat preferences. 
First cycle
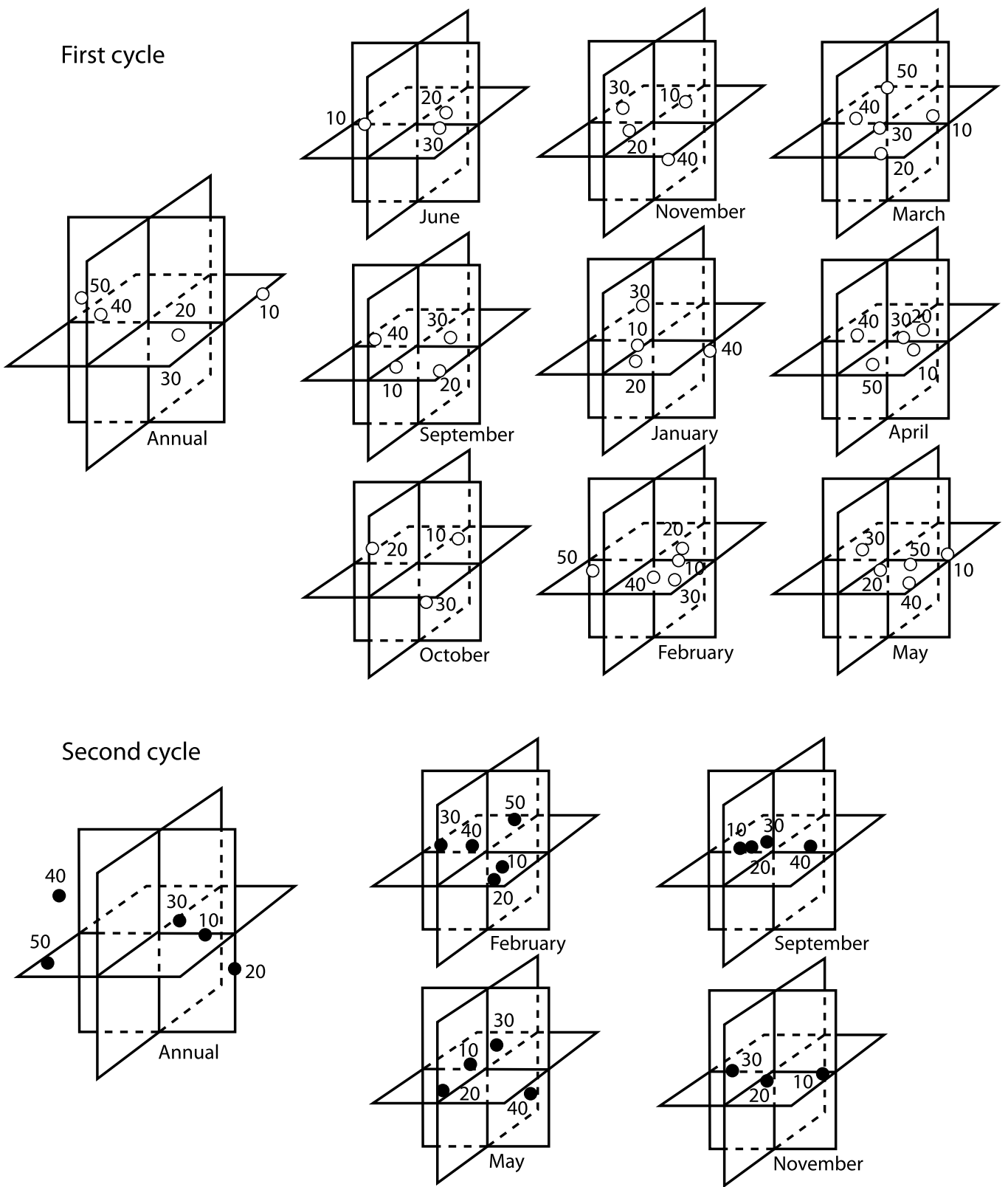

Fig. 8. Ordination of the community by depth on different months and on annual basis for each one of the two sampling years. Data show better organization of the community by mid-depths $(20-30 \mathrm{~m})$ during the summer and autumn months. Temperature and substratum stability seem to he the two main factors responsible for the organization.

Eucinostomus melanopterus, Symphurus plagusia, Saurida brasiliensis and Selene setapinnis, did so with the temperature and dissolved oxygen. From the invertebrates, the crustaceans Penaeus duorarum, Portunus spinimanus and
Sicyonia brevirostris presented negative correlations with the temperature and the oxygen same as the mollusk L. pealeii; The echinoderm Mellita lata presented negative relationships with the salinity and temperature. 
TABLE 2

Percentage of species of each faunistic group that presented negative values in the Spearman's correlation of abundance versus environmental factors

$\begin{array}{lccc}\text { Group } & \text { Salinity } & \text { Temperature } & \begin{array}{c}\text { Disolved } \\ \text { oxigen }\end{array} \\ \text { Fishes } & 1.5 & 14.5 & 16 \\ \text { Mollusks } & 4.5 & 4.5 & 4.5 \\ \text { Echinoderm } & 8.3 & 8.3 & 8.3 \\ \text { Crustacean } & 5.3 & 15.8 & 15.8\end{array}$

Trophic niches: the analysis shows that there are three main species sharing the main food resources. One depends upon the detritus (Group I); the second is mainly ichthyophagous and group omnivorous (Fig. 9). Excluding the detritic from the analysis, the asociations becomes more evident, and four clusters are shown. Two groups depend on decapods as the main food; however, fish and stomatopods are also important for that group and therefore, it is considered to be composed by specialists (Richards 1983). The third group shows two other associations, one of which is formed by omnivorous fishes, such as Eucinostomus melanopterus (Bleeker) and Chloroscombrus chrysurus (L.); the second being formed by ichthyophagus fishes from different levels of the water column with squids as a secondary diet. The last group includes species consuming large quantities of palemonids decapods.

\section{DISCUSSION}

Environmental viariations: the environmental mosaic that appeared with the monthly registries is more heterogeneous than the quarterly ones, with high and low very precise values in some months and for some certain depth. The interannual fluctuations were more evident with the temperature, which can be originated by the influence of natural events like are the tropical north and storms that are frequent in this zone and which they frequently carry cold winds, which affects in a determining way the first layers of the water column (Guido and Mathews 2000). The salinity and oxygen follow similar progressions, presenting nodules of high concentration in such months and very near depths, which sets in evidence a certain stability through the time with these parameters.

Diversity and relative abundance: the highest diversity values seem to be related to variations in the available food. However, the best organized part of the community was found between 40 and $50 \mathrm{~m}$ deep, where the equitability is highest. The less organized part was found in shallow water and it can be attributed to the mobility of the species and to the instability of the environment (Francis and Williams 1995, Gelwick et al. 2001). The best organized part of the community seems to be at the level of $30 \mathrm{~m}$, specially in February and in September. The highest diversity found at the mid-depth levels, lead us to the assumptions that there is a high number of food links (Pequeno and Lamilla 2000). This could be expected in a well-organized community which multiplies its interconnections seasonally (Madrid et al. 1977, Rocha and Rosa 1977). However, similar observations (Margalef 1969, Pennington and Godø 1995) lead us to conclude that the consistency and persistence of the community are both high.

Community patterns: because of the classification analysis, fish components are probably the main factor explaining the persistency of the community. However, although there is consistency at mid-depths, we conclude that both the structure, and the changes in structure, results from biological interactions determined by the spatial heterogeneity of the resources as well as by their seasonal variation (Garcia-Rubies et al. 1995, Cerda et al. 1997, Koranteng 2001). The benthic and demersal groups are best defined and their main source of energy is detritus. Their components have characteristically low mobility and therefore are closely linked to the substratum. Bottom dwellers are often less affected by 

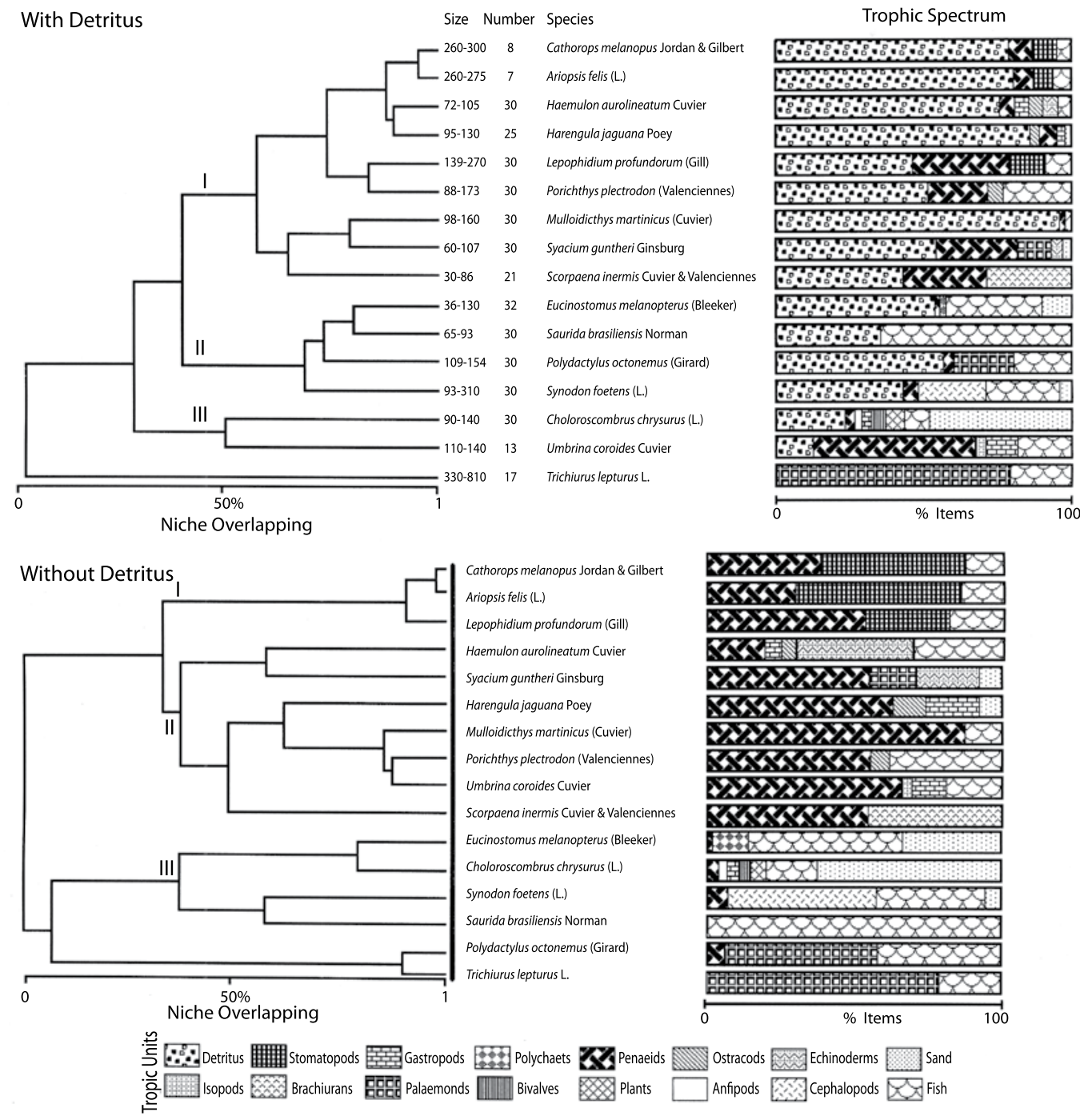

Fig. 9. Trophic spectrum of 16 out of the most common fish species showing overlap of trophic niche. The horizontal bar show the percent item gut. It is remarkable the dependence of detritus as main food source of the community.

environmental instability than the near surface ones and density dependent processes are thus more important as regulators of population size (Angermeir and Smogor 1995, Thrush et al. 2001). By contrast, the mid-water and near surface organisms are more dependent on primary productivity and on environmental instability (Livingston 1980). A small part of this group is formed by nonpermanent elements which make use of the resources of this community during its migrations (Prena 1995, Fievet et al. 2001). Both yearly samples gave similar results in terms of composition and structural organization of the community. It is thus very likely that this structure has developed under relatively constant conditions. From this, it may be concluded that the patterns shown by the community are the result of real ecological processes, and not artifacts of sampling.

The main environmental factor responsible for the highest variability in the community was temperature, so it was used as the first 
axis of ordination in Fig. 7. This is in agreement with the findings by Flint (1981), Flint et al. (1981 and 1986) in the Northern Gulf of Mexico shores. The second component seems to be linked to the stability of the substrate, the dissolved oxygen, and to the turbulence of water masses. Heck et al. (1980), Benchley (1981), Chester et al. (1983) and Thrush et al. (2001) have remarked on the importance of the substrate, whose variations may lead to small scale changes of microhabitats and also may play an important role in processes of deposition and stabilization of sediments, in buffering hydrodynamic effects, and in availability of shelter and food. The community variations are more evident bimonthly in the temporal context; however, the space variations stay all year along and the pattern is a decrease in the demersal fauna at both ends of depth and greater diversity and richness to intermediate levels. In spite of the fact that the Spearman's correlations show that few species have negative relationship with the environmental factors which corroborate the results gotten with the cluster and PCA analysis, the invertebrate fraction has better consistency in the analysis, since the multivariate analysis shows similar faunistic associations like the species that have negative correlations with the Spearman's index and that form a well defined group with the cordal distance, from which it is evident that the formation of groups are influence by the environment.

Trophic niches: the inclusion and exclusion of the detritus in the niche overlapping analysis, it was carried out with the objective of knowing in more detail the importance of the other components in the diet of the demersal fishes, since upon being link with the bottom layer, the ingestion of this component could be incidental, for which we wanted to explore the associations and interactions of the species with both strategies. With reference to the trophic niche, decapod crustaceans and fishes are the preferred prey of epibenthic predators; this explains the high niche overlap, suggesting that there one strong competition pressures
(Winemiller 1989, Hessen et al. 1995, Plattel and Porter 2001). Thus it appears that the trophic structure can be divided into two general groups: carnivores with sympatric species with relative overlap of food preferences (some species overlapping avoid, feeding of supplementary organisms that are distributed in other levels of the water column, like it is the case of Synodus foetens and Saurida brasiliensis), and a group of benthic omnivores, with a large number of species having small population densities. When the trophic niche overlap decreases, as occurs when the size differences between individuals of two species are large, then the availability of prey tends to further increase the overlap their food preferences (Zajac et al. 1989, Linke et al. 2001).

\section{ACKNOWLEDGMENTS}

This paper would not have been possible without the able assistance of Ma. Jesús Parra A. and José Luis Castro A. We also thank Rigoberto Corona and Juan Menchaca for their help with various parts of the field and laboratory work; and Rodrigo Rodriguez for language support. The fauna samples are in the Collection of the National School of Biological Science.

\section{RESUMEN}

Se analizaron los patrones estructurales de la comunidad sublitoral a través de dos años de muestreo. Los grupos involucrados en el estudio fueron: peces, moluscos, equinodermos y crustáceos. Las progresiones espacio-temporales de la diversidad de segundo orden para el primer año se encuentran entre los intervalos de $\mathrm{N}_{2}=5.3$ y $\mathrm{N}_{2}=9.8$ en las profundidades de 40 y $20 \mathrm{~m}$ respectivamente. En el segundo periodo el valor más alto $\left(\mathrm{N}_{2}=22.2\right)$ fue registrado a 30 $\mathrm{m}$. La ordenación de la comunidad a través del análisis de agrupamientos y de Componentes Principales, muestran 5 ensamblajes: béntico, béntico-demersal, demersal, a media columna de agua y temporal. Hay una fuerte diferencia en la estructura de la red trófica entre las estaciones de secas y lluvias. La repartición de recursos en la comunidad de peces, muestran que sus componentes están organizados en tres gremios: Ictiófagos, Carcinófagos y Omnívoros. Sin embargo, comúnmente se presenta un solapamiento parcial 
en el nicho, los estadíos juveniles muestran un espectro trófico muy cercano a los adultos.

Palabras clave: invertebrados marinos, peces, composición de comunidad, diversidad, espectro trófico, Golfo de México, Veracruz.

\section{REFERENCES}

Angermeir, P.L. \& R.A. Smogor. 1995. Estimating number of species and relative abundance in stream-fish communities: effects of sampling effort and discontinues spatial distribution. Can. J. Fish. Aquat. Sci. 52: 936-949.

Axis-Arroyo, J., J. Mateu \& D. Torruco. 2001. Analysis of the spatio-temporal distribution on biological species, p. 191-209. In J. Mateu \& F. Montes (eds.). Proc. $1^{\text {st }}$ spanish workshop on spatio-temporal modelling of environmental processes. Jaume I University Publications, Castellón, Spain.

Bachelet, G., X. de Montaudovin \& J.C. Dauvin. 1996. The quantitative distribution of subtidal macrozoobenthic assemblages in Arcachon Bay in relation in environmental factors: A multivariate analysis. Est. Coast. Shelf Sci. 42: 371-392.

Benchley, G.A. 1981. Disturbance and community structure: An experimental study of bioturbation in marine soft- bottom environments. J. Mar. Res. 39: 767-790.

Bireley, E.L. 1984. Multivariate analysis of species composition of shore zone fish assemblages found in Long Island Sound. Estuaries 7: 242-247.

Boesh, D.F., M.L. Wass \& R.W. Virnstein. 1977. The dynamics of estuarine benthic communities, p. 17-38. In M. Wiley (ed.). Estuarine Processes I. Uses, Stress and Adaptation to the Estuary. Academic, London, England.

Cerda, R., G. Caille \& J.C. Braccalenti. 1997. Seasonal changes and associated biogeographical aspects of coastal fish communities of Southern Santa Cruz (Argentina). Naturalia Patagónica Cienc. Biol. 5: 55-66.

Chang, D.H. \& H.G. Gauch. 1986. Multivariate analysis of plant communities and environmental factors in Ngari, Tibet. Ecology 67: 1 568-1 575.
Chester, A.J., R.L Ferguson \& G.W. Thayer. 1983 Environmental gradients and benthic macroinvertebrates distribution in a shallow North Carolina Estuary. Bull. Mar. Sci. 33: 282-295.

Escurra, E. 1980. Una nota acerca de la diversidad. Ecología 4: 141-142.

Fievet, E., S. Doledec \& P. Lin. 2001. Distribution of migratory fishes and shrimps along multivariate gradients in tropical island stream. J. Fish Biol. 59: 390-402.

Flint, R.W. 1981. Gulf of Mexico outer Continental Shelf benthos: macroinfaunal -environmental relationships. Biol. and Ocean. 1: 135-145.

Flint, R.W. \& N. Rabalais. 1981. Environmental studies of a marine system: South Texas Outer Continental Shelf. Texas University, Texas, Mexico. 210 p.

Flint, R.W. \& R.D. Kalke. 1986. Niche characterization of dominant estuarine benthic species. Est. Coast. Shelf Sci. 22: 657-674.

Francis, M.P. \& M.W. Williams. 1995. Diel variation in trawl catches of Pagurus auratus (Sparidae). Fish. Res. 24: 301-310.

Garcia-Rubies, A. \& E. Macpherson. 1995. Substrate use and temporal pattern of recruitment in juvenile fishes of the Mediterranean littoral. Mar. Biol. 124: 35-42.

Gelwick, F.P., S. Akin, D.A. Arrigton \& K.O. Winmiller. 2001. Fish assemblages stucture in relation to environmental variation in a Texas Gulf coastal wetland. Estuaries 24: 285-296.

Gido, K.B. \& W.J. Mathews. 2000. Dynamics of the offshore fish assemblage in a Southwestern reservoir (Lake Texoma, Oklahoma-Texas). Copeia 4: 917-930.

Gilinsky, E. 1984. The role of fish predation and spatial heterogeneity in determining benthic community structure. Ecology 65: 455-468.

Gnanadesikan, R. 1977. Methods for statistical data analysis of multivariate observations. Wiley- Interscience Publ, New York, USA. 310 p.

Gunter, G. 1945. Studies on marine fishes of Texas. Inst. Mar. Sci. Univ. Texas 1:1-90. 
Heck, J.R.K.L. \& R.J. Orth. 1980. Seagrass habitats: the role of habitat complexity, competition depredation in structuring associated fish and motile macroinvertebrate assemblages, p. 449-469. In V. Kennedy (ed.). Estuarine Perspectives. Academic, New York, USA.

Hessen, D.O., B.A. Fafeng \& T. Andersen. 1995. Replacement of herbivore zooplankton species along gradients of ecosystem productivity and fish depredation pressure. Can. J. Fish. Aquat. Sci. 52: 733-742.

Hildebrand, H.H. 1955. A study of the fauna of the pink shrimp (Penaeus duorarum Burkenroad). Grounds in the Gulf of Campeche. Institute of Marine Science University Texas 4: 169-232.

Hill, M.O. 1973. Diversity and evenness a unifying notation and its consequences. Ecology 54: 427-432.

Horn, H.S. 1966. Measurement of 'overlap' in comparative ecological studies. Am. Nat. 100: 419-424.

Hughes, R.G. 1984. A model of the structure and dynamics of benthic marine invertebrate communities. Mar. Ecol. Prog. Ser. 15: 1-11.

Koranteng, K.A. 2001. Structure and dynamics of demersal assemblages on the continental shelf and upper slope of Ghana, West Africa. Mar. Ecol. Prog. Ser. 220:1-12.

Linke, T.E., M.E. Platell \& I.C. Porter. 2001. Factor influencing the partitioning of food resources among six fish species in a large embayament with yuxtaposing bare sand and seagrass habitats. J. Exp. Biol. Ecol. 266:193-217.

Livingston, R.J. 1980. 0ntogenethic trophic relationships and stress in a coastal seagrass systems in Florida, p. 423-435. In V. Kennedy (ed.). Estuarine Perspectives, Academic Press, New York, USA.

Madrid, J., P. Sánchez \& A. Ruiz. 1997. Diversity and abundance of a tropical fishery on the Pacific shelf of Michoacan, México. Est. Coast. Shelf Sci. 45: 485-496.

Margalef, R. 1969. Diversity and stability: a practical proposal and model of interdependence, p. 25-37. In Brokhaven symposia in Biology. Diversity and stability in ecological systems. National Technical Information Service, Springfield, Illinois, USA.

Merino, M. 1986. Aspectos de la circulación costera superficial del Caribe mexicano con base en observaciones utilizando tarjetas de deriva. An. Inst. del Mar y Limnol. UNAM. 13:31-46.
Merino, M. 1987. The coastal zone of Mexico. Coast. manage. 15:27-42.

Orlóci, L. 1978a. Ordination by resemblance matrices, p. 94. In R.H Whittaker (ed.). Ordination of plant communities. Dr. W.J.Junk, The Hage, Netehrlands.

Orlóci, L. 1978b. Multivariate analysis in vegetation research. Dr. W.J.Junk, The Hage, Netehrlands.

Overstreet, M.P. \& D.W. Heard. 1982. Food contents of six commercial fishes from Mississipi Sound. Gulf Res. Rep. 7: 137-149.

Pennington, M. \& O.R. Godø. 1995. Measuring the effect of changes in catch ability on the variance of marine survey abundance indices. Fish. Res. 23: 301-310.

Pequeño, G. \& J. Lamilla. 2000. The littoral fish assemblages of the Desventuradas Islands (Chile) has zoogeographycal affinities with the Western Pacific. Glob. Ecol. Biog. 9: 431-437.

Pielou, E.C. 1984. The interpretation of ecological data: A premier on classification and ordination. Wiley-Interscience Publ., New York, USA. 321 p.

Platell, M.E. \& I.C. Porter. 2001. Partitioning of food resources amongst 18 abundant benthic carinivorous fish species in marine water on the lower West of Australia. J. Exp. Biol. Ecol. 261: 31-54

Prena, J. 1995. Temporal irregularity in the macrobenthic community and deep water advection in Wismar Bay (Western Baltic Sea). Est. Coast. Shelf Sci. 41: 705-718.

Rice, J.C. 1988. Repeated cluster analysis of stomach contents data: Method and application to diet of Cod in NAFO Division 3L. Environ. Biol. Fishes 21: 263-277.

Richards, L.J. 1983. Hunger and the optimal diet. Am. Nat. 22: 326-334.

Rocha, L.A. \& J.L. Rosa. 2001. Baseline assesment of reef fish assemblages of Parcel Manuel Luiz Marine State Park, Maranhão, North-east Brazil. J. Fish Biol. 58: 985-998.

Sneath, P.H. \& R.R. Sokal. 1974. Numerical taxonomy. The principles and practice of numerical classification. W.H. Freeman and Co., New York, USA. 320 p.

Strickl, J.D.H. \& T.R. Parsons. 1972. A practical handbook of sea water analysis. J. Fish. Res. Board Can, Ottawa, Canadian. 167 p. 
Swartz, R.C., F.A. Cole, D.W. Schults \& W.A. Deben. 1986. Ecological changes in the Southern California Bright near a large sewage outfall Benthic conditions in 1980-1983. Mar. Ecol. Prog. Ser. 31: 1-13.

Thiestle, D. 1981. Natural physical disturbance and communities of marine soft-bottom. Mar. Ecol. Prog. Ser. 6: $223-228$

Thorman, S. 1983. Food habitat resource partitioning between three estuarine fish species of the swedish West Coastal. Est. Coast. Shelf Sci. 17: 681-192.

Thrush, S.F., J.E. Hewitt, G.A. Connell, U.J. Cummings, J. Ellis, D. Schultz, D. Talley \& A. Morkko. 2001 Fish disturbance and marine biodiversity: the role of habitats structure in simple soft-sediment systems. Mar. Ecol. Prog. Ser. 221: 255-264.

Watzin, M.C. 1983. The effects of meiofauna on setting macrofauna: meiofauna may structure macrofaunal communities. Oecologia 59: 163-166.

Winemiller, K.O. 1989. Ontogenetic diet shifts and resource partitioning among piscivorus fishes in the Venezuelan Llanos. Environ. Biol. Fishes 26: 177-199.

Zajac, R.N., R.B. Whithatch \& R.W. Osman. 1989. Effects of the interspecific density and food supply on survivorship and growth of newly a settled benthos. Mar. Ecol. Prog. Ser. 56: 127-132. 